\title{
Global environmental change: local perceptions, understandings, and explanations
}

\author{
$\underline{\text { Aili Pyhälä }}^{1,2}$, Álvaro Fernández-Llamazares $^{1,2}$, Hertta Lehvävirta $^{2}$, Anja Bvg $^{3}$, Isabel Ruiz-Mallén $^{1,4}$, Matthieu Salpeteur $^{1,5}$ \\ and Thomas F. Thornton ${ }^{6}$
}

\begin{abstract}
Global environmental change (GEC) is an increasingly discussed phenomenon in the scientific literature as evidence of its presence and impacts continues to grow. Yet, while the documentation of GEC is becoming more readily available, local perceptions of GEC - particularly in small-scale societies - and preferences about how to deal with it, are still largely overlooked. Local knowledge and perceptions of GEC are important in that agents make decisions (including on natural resource management) based on individual perceptions. We carried out a systematic literature review that aims to provide an exhaustive state-of-the-art of the degree to and manner in which the study of local perceptions of change are being addressed in GEC research. We reviewed 126 articles found in peer-reviewed journals (between 1998 and 2014) that address local perceptions of GEC. We used three particular lenses of analysis that are known to influence local perceptions, namely (i) cognition, (ii) culture and knowledge, and (iii) possibilities for adaptation. We present our findings on the geographical distribution of the current research, the most common changes reported, perceived drivers and impacts of change, and local explanations and evaluations of change and impacts. Overall, we found the studies to be geographically biased, lacking methodological reporting, mostly theory based with little primary data, and lacking of indepth analysis of the psychological and ontological influences in perception and implications for adaptation. We provide recommendations for future GEC research and propose the development of a "meta-language" around adaptation, perception, and mediation to encourage a greater appreciation and understanding of the diversity around these phenomena across multiple scales, and improved codesign and facilitation of locally relevant adaptation and mitigation strategies.
\end{abstract}

Key Words: adaptive strategies; cognitive psychology; local knowledge; ontologies; small-scale societies

\section{INTRODUCTION}

Global environmental change (GEC) is an increasingly discussed phenomenon in the scientific literature as evidence of its presence and impacts continues to emerge from different corners of the world (Turner et al. 1990, Vitousek 1994, Steffen et al. 2004, 2011, Zalasiewicz et al. 2011) The notion of GEC refers to a set of planetary-scale changes in the Earth System (Vitousek 1994, Zalasiewicz et al. 2011, Dirzo et al. 2014), spanning from largescale changes related to the global geosphere and biosphere systems (e.g., nitrogen and carbon cycles, biodiversity loss) to changes at the local or regional scale and related specifically to human activities (e.g., waste production, extirpation of species, land use changes). The processes driving GEC result from complex articulations of human actions (IGBP 2004, IPCC 2007) as well as from biological and physical processes, sometimes resulting from the accumulation of even multiple localized processes (Turner et al. 1990). Concerns and evidence are growing for the possible implications of a major state shift in the Earth's biosphere (Barnosky et al. 2012), and according to some, we are now living in a new geological epoch, the Anthropocene, in which human actions dominate Earth's systems (Crutzen 2002, Crutzen and Steffen 2003, Zalasiewicz et al. 2008, Ruddiman 2013).

In general, environmental change has been described by scholars as an integrative, all-encompassing, and even cyclical process (Sánchez-Cortés and Chavero 2011, Habiba et al. 2012, Boillat and Berkes 2013), with significant social dimensions (Byg and Salick 2009, Petheram et al. 2010). Despite this, most of the research examining local aspects of GEC has applied a top-down perspective (Wilbanks and Kates 1999). Using global modeling techniques, the normative aim has been to assess and predict impacts at highly localized scales and in specific settings (Schneider and Root 1996). However, due to the low resolution of global models at the local scale, some authors are starting to untangle the complex interconnection of GEC processes using a bottom-up approach, from the local to the global (Cox 1997, Byg and Salick 2009). Yet, while causes of GEC are better studied at the local level, GEC dynamics are observed mostly at the global scale but with responses and adaptations occurring at all levels (Wilbanks and Kates 1999, Adger et al. 2005, Wiens and Bachelet 2010).

While the documentation of GEC is becoming more readily available, with ever more sophisticated devices capable of capturing large-scale biophysical changes, local accounts of the impacts of GEC are still relatively overlooked. Indeed, most research to date has focused on the biophysical aspects of GEC, and it is only recently that the social sciences and the humanities have started to make their contribution. Social scientists concerned with GEC have tended to center on vulnerability and adaptation (Burton et al. 2002, Agrawal 2008, Thornton and Manasfi 2010) and risk perceptions (Tàbara et al. 2010) with regard to climate change, with the aim of measuring and modeling the relative vulnerability of particular regions, communities, or resources to predicted changes (e.g., Brooks et al. 2005, Erlandson 2012). This is a critical gap in global environmental science, as GEC has the potential to reduce the well-being and security of people locally and around the world, especially when exacerbated by social, political, and economic unrest.

${ }^{1}$ Institut de Ciència i Tecnologia Ambientals (ICTA), Universitat Autònoma de Barcelona (UAB), Spain, ${ }^{2}$ Metapopulation Research Centre, Dept. of Biosciences, University of Helsinki, Finland, ${ }^{3}$ Social, Economic and Geographical Sciences Group, James Hutton Institute, UK, ${ }^{4}$ Internet Interdisciplinary Institute (IN3) - Universitat Oberta de Catalunya (UOC), ${ }^{5}$ ERAAUB, Departament de Prehistòria, Història Antiga i Arqueologia, Universitat de Barcelona (UB), Spain, ${ }^{6}$ Oxford University, School of Geography and the Environment 
Recent calls for more social science research on GEC have come from a number of scholars (Monastersky 2009, Hulme 2011, Turnhout et al 2012, Barnes et al. 2013, Castree et al 2014, Victor 2015). There are a number of reasons why understanding local perceptions of change is important. Firstly, an insight into local perceptions can improve our understanding of GEC in its various manifestations and impacts on human populations. As an example, discrepancies between local perceptions of change and instrumental records (Marin 2010) illustrate the potential contribution that these can make in discovering new elements of GEC. Secondly, people's perceptions may well determine their behavior toward mitigation and adaptation actions (Stern 2000, Vignola et al. 2010, Engels et al. 2013), and are therefore a key ingredient in the design, planning, and implementation of successful GEC adaptation strategies that are adequate for local realities, be they social, cultural, or environmental (Patt and Weber 2014). Local perceptions are thus of direct relevance to any initiatives aiming for sustainable natural resource management, biodiversity conservation, or climate change adaptation and mitigation.

Given this situation, a handful of scientists have begun to undertake research on local understandings of environmental change among indigenous and local communities and other small-scale societies (e.g., Lykke et al. 2004, King et al. 2007, Green et al. 2010, Boillat and Berkes 2013, Kansiime et al. 2013), demonstrating the potential of local peoples' observations for the understanding of the local expressions of GEC (Byg and Salik 2009). We set out to review this literature to critically review the ways in which local understandings are captured and presented in the research. We approach this study from multiple perspectives, exploring aspects such as scale, geographic distribution, cognitive mechanisms, cosmologies, and values, and to what degree studies of GEC and local perceptions take into account these factors that might well be influencing the results. In addition, we review the literature with an interest in understanding why researchers study local perceptions of GEC, for what purpose or end.

To guide us through this, we framed our study in relation to three particular thematic foci. We questioned to what extent GEC research takes into account (1) the influences that cognitive psychology may have on local perceptions, (2) the role that local cosmologies, epistemologies, and ontologies play, and (3) whether and how local small-scale societies might be taking measures to adapt to environmental change. By "small-scale societies" we mean societies of a few dozen to several thousand people who live by foraging wild foods, herding domesticated animals, or conducting nonintensive horticulture at the village level. To contextualize our review, we present some general findings on the geographical and thematic foci of the literature, and how it reports (a) the types of environmental change perceived, (b) local explanations of the change occurrence and manifestation, including in time and scale as well as in terms of drivers and impacts, and (c) local evaluations of the change and its impacts. Our study is innovative in that it is the first - to our knowledgethat undertakes a comprehensive review of the existing research on local perceptions of GEC while using a critical perspective.

We present a theoretical background to our research design and analysis, touching upon elements of scale and causation, cognition, culture and knowledge, and adaptation. We then present a descriptive overview of our results, followed by a more comprehensive analysis around the three overarching themes of the paper, namely cognition, ontologies, and adaptation. We discuss the implications of our findings for the broader research on GEC, and the repercussions these might have for planning local adaptation and mitigation strategies.

\section{THEORETICAL BACKGROUND}

The purpose of this research was to undertake a systematic literature review with the aim of providing an exhaustive stateof-the-art of the extent to and manner in which GEC research addresses local perceptions in small-scale societies. To do so, we used three particular lenses of analysis that are known to influence local perceptions, namely (i) cognition, (ii) culture and knowledge, and (iii) possibilities for adaptation. We present and elaborate on each of these three thematic strands.

\section{Cognition in global environmental change perception}

In addition to scale and causation, equally important to local perceptions is cognition: the rates of temporal change in local perceptions (e.g., Deryungina 2012), perceptibility itself (e.g., Weber 2013), and the role that the reception of external scientific information may play in influencing local perceptions (e.g., Marin and Berkes 2012, Fernández-Llamazares et al. 2015a). Understanding the role that cognition plays in GEC perceptions is important for at least three main reasons. First, studies indicate that different psychological processes play a key role in shaping individual framings of environmental change (e.g., Stamm et al. 2000, Helgeson et al. 2012, Howe and Leiserowitz 2013). Examples of such processes include memory illusions, change blindness, and the Shifting Baselines Syndrome. Memory illusions refer to exaggerations of the extent of trends, which may also have been caused by the influential memory of extreme events (Roediger 1996, Kahn 2002, Daw 2010). Change blindness refers to the failure to observe local indicators of climate change; that is, the desensitization to change (e.g., Simons and Rensik 2005, Alessa et al. 2008). Shifting Baselines Syndrome refers to a type of change in how a system is measured or perceived, usually against previous reference points (baselines), which themselves may represent significant changes from an even earlier state of the system (see e.g., Papworth et al. 2009, Fernández-Llamazares et al. 2015b). Second, many works describe how experiential knowledge acquired through daily observation of the environment - accurate or not-generally overrides descriptive knowledge gained through the uptake of scientific information (Myers et al. 2013, Egan and Mullin 2014, Zaval et al. 2014, Yeh 2015). In other words, agents make decisions (e.g., on the use of natural resources) based on individual perceptions rather than on measured variables or more diagnosed criteria (Oba and Kotile 2001, Maule and Hodgkinson 2002, Voyer et al. 2012). And third, the research to date suggests that the way in which people perceive environmental changes influences how they respond to them (Weber and Johnson 2009, Vignola et al. 2010, Spence et al. 2011).

Yet, human perceptibility of GEC (particularly climate change) has been somewhat disputed in the last decades (see RudiakGould 2013). While some argue that global changes are beyond the threshold of human perception over the course of a lifetime (Mormont and Dasnoy 1995, Doyle 2009, Spence et al. 2011), others claim that the effects of GEC are visible to the naked eye 
(Riedlinger and Berkes 2001, Green et al. 2010). Responses to this debate are blurred by the meagre empirical research on the topic and partially explain the increasing interest in understanding the way in which people frame environmental changes from a psychological point of view (Swim et al. 2009, Howe et al. 2012, ISSC and UNESCO 2013). Nevertheless, our current understanding of psychology in GEC remains poor and biased, the latter in that the cognitive science that has been carried out to date has been limited largely to climate change perceptions and to what Henrich et al. (2010) term as "WEIRD" (Western, Educated, Industrialized, Rich, and Democratic) societies (Capstick et al. 2014). Such biases are of concern, especially as local knowledge and individual perceptions often form the basis upon which many small-scale societies monitor availability and thus manage natural resources (Maule and Hodgkinson 2002). In other words, local perceptions are critical in designing successful and sustainable natural resource management schemes among small-scale societies wherever they may be (Oldekop et al. 2012).

\section{Culture and knowledge}

Beyond the psychological and socioeconomic considerations that GEC entails, there is also a need to understand how GEC is converted into a culturally relevant form at the local level (ISSC and UNESCO 2013). Research already shows the importance of existing epistemic frameworks, local systems of knowledge, and vernacular systems of classification in studying local perceptions of environmental change (Gupta 1999, Lakoff 2010). This body of research relies mainly on concepts and ideas developed in environmental anthropology and ethnoecology (e.g., Brosius 1999, Kottak 1999, Nazarea 1999), and focuses on the study of systems of local knowledge (hereafter LK) (Berkes 1999, Davis and Wagner 2003) and stresses the fact that, beyond psychological aspects, such systems also include theoretical, practical, and symbolic dimensions (Nadasdy 2007, Reo and Whyte 2012).

As Berkes (2009) has already put forth, local perceptions of environmental change need to be understood as part of larger systems of knowledge that have been developed locally, through repeated interactions with the environment, and that have been handed down over generations. In addition, local perceptions may also integrate with local values (including economically driven commodification and utility values), as well as with hybridized knowledge coming from external sources such as NGOs, governmental agencies, or media channels (Dove et al. 2007, Li 2007, Leonti 2011, Rudiak-Gould 2014). Therefore, the way in which people perceive and experience environmental change will most likely be shaped at least partly by the existing vernacular conceptions of the environment, be it referred to or theorized as local cosmologies, local classification systems, or ontological regimes (Orlove et al. 2002, Descola 2005).

\section{Adaptation to global environmental change}

All the above-mentioned perceptual differences have implications for people's cultural representations of the environment, which in turn, largely define the possible strategies for coping with - and enacting with - change (Manandhar et al. 2011, Boissière et al. 2013, Yu et al. 2014). For example, differences in perceptions of climate change across gender and age groups in Ethiopia have been found to affect local adaptation preferences (Deressa et al. 2009). Not surprisingly then, adaptation has become an increasing focus in GEC literature, and particularly climate change literature, as human vulnerabilities to the impacts of change (regardless of mitigation efforts) have become manifest and irreversible. Some studies have already begun to highlight the importance of local understandings of GEC for adaptation policies in particular, especially as they can compensate for the lack of formal scientific data on local effects of environmental change, and to inform locally sound resource governance (Laidler 2006, Bunce et al. 2008, Newsham and Thomas 2011, Robbins 2012). However, a problem with the literature to date on climate and GEC adaptation is the difficulty to isolate precisely what drivers and impacts people are responding to. Locally experienced stress and vulnerability likely arise from multiple sources, among which GEC drivers and impacts may be secondary to more proximate ones; e.g., socioeconomic trends. In our review, we therefore use a multifaceted approach to assessing how adaptation has been addressed in the GEC literature.

\section{METHODS}

In order to access articles that address local perceptions of GEC, we used the search engine Web of Science (http://wokinfo.com/) to run our search. We inserted the following keyword phrases: "Local Perceptions Global Environmental Change," "Local Perceptions Climate Change," "Indigenous Climate Change," "Indigenous Perceptions Climate Change," "Indigenous Local Environmental Change," and "Small-scale Society Environmental Change." First, we compiled all relevant articles published up to mid-2014, which gave us a total of 176 articles. We did a general but careful review of all of these to filter out any articles that might not fit our criteria; i.e., they had to be case studies that substantially addressed local perceptions or contemporary environmental change with actual data, rather than general theoretical papers or compilations of many cases. Through this initial scan, we eliminated 50 articles, which left us with a total of 126 articles - all published in peer-reviewed journals between 1998 and mid-2014 (see Appendix 2 for the full list of articles reviewed).

We then designed a database matrix framed according to our key research questions and the variables that would help us answer them. We pilot tested the matrix by initially reviewing 13 randomly selected articles from our first sample set, and made the necessary adjustments to the matrix to maximize quantitative data entry and applicability across a variety of case studies while maintaining the level of detail we sought to have. We then decided on a final template for the matrix (see Appendix 1), and set up a database in which to enter our data. Responses to GEC were analyzed using a meta-language of adaptation processes developed by Thornton and Manasfi (2010) (see also Agrawal 2010). For a more detailed explanation of our methodology and analysis, see Appendix 1. Table 1 lists those variables for which we present findings. Appendix 3 contains the full matrix of the results presented here.

\section{RESULTS}

\section{Descriptive results}

Thematic and geographical foci

The 126 articles we reviewed spanned more than 56 journals, mostly from the following: Global Environmental Change, Climatic Change, Arctic, Indian Journal of Traditional Knowledge, Ecology and Society, Environmental Management, Land 
Table 1. Variables for which data were collected, with scales and categories of analysis.

\begin{tabular}{|c|c|}
\hline Variable & Description (including codes and categories) \\
\hline Geographical focus of study & (i) Continent (pre-coded into seven categories), and (ii) region (pre-coded into 28 categories) \\
\hline Goals of article & $\begin{array}{l}\text { Whether (a) documenting change and (b) comparing scientific data with local perceptions were the main goal (1), one of } \\
\text { many goals (2), or not a goal (3) of the article }\end{array}$ \\
\hline Methods of data collection & Whether quantitative (1), qualitative (2), or both (3) \\
\hline Type of change perceived & $\begin{array}{l}\text { Pre-coded into } 16 \text { categories: temperature change, rainfall change, drought, erosion, floods, sea level rise, deforestation, } \\
\text { biodiversity change, invasive species, permafrost/ice/glaciers, fire, winds (excluding tornadoes/cyclones), storms, extreme } \\
\text { events (including tornadoes/cyclones/tsunamis/earthquakes), phenology/seasonality, or other. This was recorded for up to } \\
\text { seven different types of environmental change per article. }\end{array}$ \\
\hline Perceived driver of change & $\begin{array}{l}\text { Whether perceived as human-induced (1), a natural phenomena (2), induced by supernatural/religious/cosmological forces } \\
\text { (3), or other (4) }\end{array}$ \\
\hline $\begin{array}{l}\text { Perceived spatial impact of } \\
\text { change }\end{array}$ & Whether local (1), regional (2), global (3), or locally not perceived (4) \\
\hline Evaluation of change & Whether change was seen as positive (1), negative (2), or both (3) \\
\hline Visibility of change & Whether change was perceived by the naked eye (1), only by use of technological instruments (0), or by both (2) \\
\hline Psychology & $\begin{array}{l}\text { Whether the article took into account (1) or not ( } 0 \text { ) local psychological dimensions of the environmental perceptions (e.g., } \\
\text { shifting baselines, change blindness, amnesia, media effects) }\end{array}$ \\
\hline Conceptualizations of change & $\begin{array}{l}\text { Whether the article took into account (1) or not }(0) \text { local ethnological explanations of change (e.g., any local epistemology, } \\
\text { ontology, cosmology, cultural meaning, or other) }\end{array}$ \\
\hline Response and adaptation & $\begin{array}{l}\text { Whether the article mentioned any local responses or adaptation measures to change (yes }=1 \text {, no }=0) \text {, and if so, whether } \\
\text { these were (a) based on local knowledge (1), based on modern technology (2), or both (3), (b) locally driven }(1) \text {, externally } \\
\text { driven (e.g., by NGOs, development aid, scientists, government) (2), or both (3) }\end{array}$ \\
\hline
\end{tabular}

Degradation and Development, and Regional Environmental Change. Overall, we found great variation in both the thematic foci and types of GEC that the articles covered. The most common topics were vulnerability assessment, local weather, adaptive strategies, LK systems, and local observations of environmental change. However, even within the same thematic area, articles varied in terms of focus. For instance, some authors addressed specifically socioeconomic vulnerability (increasing poverty, unemployment, disease), while others focused more on cultural vulnerability (e.g., local traditions). Most case studies were from Africa, followed by North and Central America, and thirdly Asia. Table 2 outlines the geographic distribution of the studies in relation to continent and region.

Table 2. Geographic representation of articles reviewed.

\begin{tabular}{|c|c|c|c|}
\hline Continent & $\begin{array}{l}\text { No. of } \\
\text { Articles }\end{array}$ & Region & $\begin{array}{l}\text { No. of } \\
\text { Articles }\end{array}$ \\
\hline \multirow[t]{6}{*}{ Africa } & 36 & Southern Africa & 8 \\
\hline & & Horn of Africa & 8 \\
\hline & & East Africa & 7 \\
\hline & & Sahel & 7 \\
\hline & & Western Africa & 5 \\
\hline & & North Africa & 1 \\
\hline \multirow{3}{*}{$\begin{array}{l}\text { North and Central } \\
\text { America }\end{array}$} & 37 & Arctic & 33 \\
\hline & & Mexico & 3 \\
\hline & & Other & 1 \\
\hline \multirow[t]{3}{*}{ Asia } & 29 & South-Central Asia & 16 \\
\hline & & Eastern Asia & 8 \\
\hline & & South-East Asia & 5 \\
\hline \multirow[t]{3}{*}{ South Pacific } & 13 & Australia & 6 \\
\hline & & South Pacific Islands & 6 \\
\hline & & New Zealand & 1 \\
\hline \multirow[t]{2}{*}{ South America } & 6 & Amazon Basin & 4 \\
\hline & & Andean Region & 2 \\
\hline Europe & 3 & & 3 \\
\hline Total & 124 & & 124 \\
\hline
\end{tabular}

\section{Goals and methods}

For more than half the cases, studying local perceptions of change was only one of several goals of the research; for approximately one-third of the cases, this was the primary goal of the article. In only a handful of articles was the actual documentation of change (i.e., using scientific methods for change documentation) the main goal of the study. About one-third of the studies had change documentation as one of several goals, but it was not the primary goal. Meanwhile, the methods of data collection varied between quantitative only, qualitative only, and both. Many of the articles lacked methodological details; e.g., descriptions of precisely (a) what was asked of respondents, (b) to whom specifically it was asked, (c) how it was asked (i.e., exact wording, approach), and (d) when it was asked (timing and context). Less than one-third of the articles reported on sample size of the group studied, let alone sampling strategy. Approximately half the articles reported either the year(s) for which data were recorded, or the decade since change had been recorded or perceived.

\section{Types of global environmental change, drivers, and impacts}

The most commonly documented types of environmental change that were reportedly perceived by the peoples studied were phenology/seasonality, rainfall change, temperature change, and biodiversity change. For the full list of findings, see Table 3. In those articles that reported on drivers and impacts, the driver of change was perceived to be local (e.g., most commonly related to temperature change, followed by biodiversity change) in most of the cases, followed by global (mostly biodiversity then temperature change related); the least commonly reported drivers of change were regional (mostly deforestation then biodiversity change related) or were locally not perceived at all. The drivers of change were seen in most cases to be human-induced, and only in very few cases as natural phenomena, supernatural/religious/ cosmological driven, or a combination of both human and supernatural. In those articles that reported local perceptions of the spatial impacts of GEC, the change was perceived to be mainly global in most of the cases, followed by local; perceived impacts 
at regional scale were reported in only one case. The impacts were perceived to be mostly on (i) livelihoods, (ii) culture and social norms, and/or (iii) the environment. Overall, change was evaluated by local peoples (and reported in more than half the articles) as negative in most cases, or as both negative and positive in a few cases. In no cases was the change perceived by the local society as entirely positive. We discuss the possible reasons for these results further in this article.

Table 3. Types of locally perceived global environmental change reported in articles reviewed.

\begin{tabular}{lc}
\hline \hline Type of Change & No. of \\
& Articles \\
\hline Phenology/seasonality & 71 \\
Rainfall change & 70 \\
Temperature change & 69 \\
Biodiversity change & 63 \\
Permafrost/ice/glaciers & 42 \\
Unusual/unpredictable weather patterns & 42 \\
Extreme events (including tornadoes/cyclones/tsunamis/ & 39 \\
earthquakes) & \\
Drought & 38 \\
Deforestation & 28 \\
Winds (excluding tornadoes/cyclones) & 25 \\
Erosion & 23 \\
Floods & 23 \\
Storms & 23 \\
Fire & 19 \\
Invasive species & 17 \\
Sea level rise & 14 \\
\hline
\end{tabular}

\section{Cognitive psychology and perceptions of change}

Approximately half our sample reported cognitive aspects related to perceptions of change, and made direct links between the local observations of change and different psychological aspects. Cognitive processes influencing change perceptions that were given particular attention included the endowment effect (Patt and Schröter 2008), availability heuristics (Meze-Hausken 2004), change blindness (Alessa et al. 2008), and Shifting Baselines Syndrome (Ainsworth et al. 2008). Some of the articles drew on individual and group mental models to clarify the synergies and feedbacks in the linkages between change perceptions and other likelihood stressors (Bunce et al. 2009, 2010), while others showed, with the help of mental models, that people recognize linkages and feedbacks between events, processes, and causes, interwoven both at local and global scales (Bunce et al. 2010, Rai 2010).

Change was reported as able to be perceived by the naked eye (without any recording devices) in about one-third of the cases, whereas in more than half the cases the change was reportedly perceived by the naked eye and recorded with technological equipment or measurements. Some articles explored the role of visualization and sight in environmental change perception (e.g., Rudiak-Gould 2012, Li et al. 2013, Nkomwa et al. 2014), while others examined how climate change perceptions differ due to age differences (Alessa et al. 2008) or gender (Boissière et al. 2013, Li et al. 2013), both of which could be linked to age and gendered distribution of labor and environmental engagement. For example, men of a certain age who hunt (compared to men or women who do not hunt) would be more likely to perceive more changes in animal populations.

Most of the studies used an epistemological approach of constructivism, in which it is held that people construct knowledge and meaning from their social interactions and personal experiences of change (Petheram et al. 2010, Rudiak-Gould 2014). For instance, Ignatowski and Rosales (2013) reported that local peoples are particularly perceptive of biophysical factors related to safety and security. Several other authors explored local change perceptions by undertaking a risk perspective (Anik and Khan 2012, Below et al. 2012, Combest-Friedman et al. 2012), and argued that perceptions of increased risk due to uncertain and complex environmental changes are highly contingent on the social, economic, and cultural conditions within which people experience these risks (West et al. 2008, Bridges and McClatchey 2009, Ignatowski and Rosales 2013).

\section{Local cosmologies, epistemologies, and ontologies}

Almost half the articles in our sample addressed local conceptualizations of change in one way or another. Of these, very few touched on cosmology or ontology, while many more addressed epistemology. While a handful of papers touched on cosmology, they did so merely by giving some examples of perceived causality (e.g., environmental changes linked to spirits or deities) and myths (Byg and Salick 2009, Marin 2010, Lauer and Aswani 2010, Cruickshank 2011). A few papers talked more generally about other conceptualizations of nature-e.g., as personal or social relationships or something that continues to be created continuously - or mentioned the way some practices are rooted in cosmological principles as well as in practical considerations (e.g., sharing food).

As for epistemologies, the articles that addressed this mostly (e.g., Laidler 2006, Roturiera and Roue 2009, Speranza et al. 2010, Cruikshank 2001) did so when comparing what characterizes LK in contrast to Western science, and stressed the importance of the former and how it should be taken into account, although the reasons given differed. While some of the authors highlighted LK as a means to help confirm scientific observations (Ignatowski and Rosales 2013), others suggested that LK can provide additional information for scientists by supplementing scientific data (e.g., for places, time scales, or parameters that scientists have not yet measured or taken into account [cf. Roncoli 2006]). Some of the articles (e.g., Marin 2010) showed how LK can point toward areas that need more research - e.g., where there is disagreement between LK and Western science (Gearheard et al. 2010, Weatherhead et al 2010) - or highlighted the importance of LK as an asset of resilience for smallholders to respond to climate change and other social-ecological shifts (von Glasenapp and Thornton 2011, RuizMallén and Corbera 2013).

A few papers reflected on the ways in which Western science conceptualizes LK, and how the latter is used or abused (e.g., Leduc 2006). The difficulties of translation between different epistemologies (Rudiak-Gould 2012), the ways in which different kinds of knowledge become authorized (Cruikshank 2001), and how such processes constitute power (Veland et al. 2013) are some of the important points that came up in the literature. Furthermore, some of the literature acknowledged how Western science is influenced by factors other than just empirical properties 
Table 4. Adaptation processes addressed in the reviewed articles.

\begin{tabular}{|c|c|c|c|}
\hline Adaptation Process & Definition $\dagger$ & $\begin{array}{l}\text { No. of } \\
\text { Articles } \\
(n=64)\end{array}$ & Examples \\
\hline Mobility & $\begin{array}{l}\text { Seasonal movement or permanent migration to } \\
\text { avoid risk or in search of better circumstances }\end{array}$ & 54 & $\begin{array}{l}\text { Hunter mobility on Arctic sea ice; pastoralist seasonal } \\
\text { migrations; crop siting }\end{array}$ \\
\hline Exchange & Flow of material and symbolic goods and services & 52 & Knowledge exchange programs \\
\hline Rationing & $\begin{array}{l}\text { Controlling the circulation or consumption of } \\
\text { limited or critical resources }\end{array}$ & 50 & $\begin{array}{l}\text { Water conservation or recirculation in rain-fed } \\
\text { agricultural schemes }\end{array}$ \\
\hline Pooling & $\begin{array}{l}\text { Sharing or linking of assets (wealth, labor, } \\
\text { knowledge) }\end{array}$ & 39 & $\begin{array}{l}\text { Improved risk management through sharing of } \\
\text { information and technology assets }\end{array}$ \\
\hline Diversification & $\begin{array}{l}\text { Changing the portfolio of food, income sources, } \\
\text { etc. to enhance livelihoods }\end{array}$ & 64 & Changing crops, livestock, prey choices \\
\hline Intensification & $\begin{array}{l}\text { Increasing the availability of resources by boosting } \\
\text { their yield within a certain space or time }\end{array}$ & 56 & $\begin{array}{l}\text { Intensifying planting or harvesting in places with higher } \\
\text { capacity }\end{array}$ \\
\hline Innovation & $\begin{array}{l}\text { New method or technique that arises to address a } \\
\text { certain need }\end{array}$ & 41 & $\begin{array}{l}\text { New seed varieties or inputs to maintain or improve } \\
\text { agricultural yields }\end{array}$ \\
\hline Revitalization & $\begin{array}{l}\text { Organized reconfiguration of traditional } \\
\text { knowledge and practices to reduce stress }\end{array}$ & 23 & $\begin{array}{l}\text { Re-evaluating traditional weather forecasting } \\
\text { techniques in light of climate change impacts }\end{array}$ \\
\hline
\end{tabular}

of the phenomena studied (Gearheard et al. 2010, Veland et al. 2013). Many papers mentioned changes in knowledge systems due to changes in lifestyle, influence from other knowledge systems, or because of environmental changes which invalidate traditional knowledge (e.g., Ford et al. 2006).

A conceptually interesting paper by Orlove et al. (2010) differentiated between several components of LK related to climate (components of LK being somehow equivalent to domains of knowledge). The study identified four components to which people refer when dealing with climatic events: (a) historical patterns, (b) signs (i.e., symbolic or religious dimension), (c) actual weather observations, and (d) regional media information (radio, news). In contrast to most of the papers that emphasized epistemological differences between LK and scientific knowledge, Orlove et al. (2010) showed that information coming from different domains ("components") is actually used by people while interpreting ongoing climatic events. According to the authors, local people show a clear openness in selecting the information they use, and there is no apparent opposition between the different epistemologies at play; rather, they are seen to complement one another. Why local people in these cases choose to transcend epistemic boundaries is unclear, and may be linked to how different information is accessed, by whom, and in what form.

\section{Local responses and adaptation strategies to global environmental change}

Local responses to GEC were reported in more than half the papers reviewed. Such responses were based on LK in about onequarter of the articles, and relied on both LK and modern technology in a similar number of cases. Very few articles reported responses based only on technological knowledge and practices. In general, responses were locally driven (for the most part) or both locally and externally promoted, whereas those driven only by external institutions (NGOs, scientists, and government) were reported in only a handful of articles. Some articles did not include enough data to identify the type of knowledge and origin of the response.
Responses to GEC that consisted of diversification, or the process of increasing the variety of income production strategies and food, were the most frequently reported as adaptation strategies (in about half the articles) (see Table 4). Less than half the articles reported adaptation strategies based on mobility (i.e., temporary or permanent migration to avoid risk), rationing (i.e., controlling and limiting critical resources consumption or circulation), and exchange processes (i.e., increasing revenue flows). Intensification strategies aimed at increasing the utilization of resources in a certain period and location were reported in about one-third of the articles. Responses based on innovation were included in onethird of the articles, as were pooling, or the sharing of assets across social groups. Adaptation consisting of revitalization processes, or the restructuring of society cultural practices, ideology, and organization to deal with stress, were identified in about onequarter of the articles.

We also found that about one-tenth of the articles, particularly those focused on Arctic indigenous peoples, reported adaptation strategies related to forecasting, such as the observation of snowing by Saami reindeer herders to decide when to move animals (Tyler et al. 2007). Here, the emphasis on forecasting was concerned mainly with re-evaluating and aligning traditional knowledge and techniques for weather forecasting in light of changing conditions, and thus arguably could be considered a revitalization process. Hardly any articles mentioned any responses based on flexibility (e.g., in terms of when to travel on sea ice, plant crops, graze animals in certain areas). Two articles also mentioned praying as an adaptation strategy, again perhaps reflecting revitalization or revalorization of a traditional technique. One article reported strategies based on selectivity (classed as rationing), and another one identified "policy" itself as an adaptation pathway (classed as innovation, given the emphasis on new policies).

\section{DISCUSSION}

Firstly, and as mentioned in the Introduction, it is surprising how many articles in the broader GEC literature do not deal with local perceptions at all. Several reasons may explain this. First, it is 
often difficult for local people to perceive certain aspects of GEC; e.g., in the case of changes in temperature over time (a fluctuating process in itself), especially if adequate measuring instruments are not available (see Rudiak-Gould [2013] for some examples). Second, local people may face a challenge in understanding the drivers and impacts of environmental changes at the local and global scales. For instance, Wilbanks and Kates (1999) stress the difficulty local people have in drawing causal links between their daily activities and the global-level impact these have, as indirect processes are simultaneously at work in GEC induction. Third, there is the ongoing debate about what counts as knowledge with regard to valid data and science (Adams 2007). The most fundamental and consequential effect of this is that those (often mistakenly) considered "nonspecialists" are rarely given the opportunity to contribute to the GEC debate, even when they are directly affected by it.

Of those studies that looked at GEC and local perceptions of small-scale societies (i.e., the 126 articles reviewed here), there is firstly a geographical bias, particularly to Africa, the Arctic, and Asia, with very few studies for instance from Europe or South America. There may be some association between geographic representation and the patterning of goals in the articles due to scientific data availability at the scales necessary to evaluate it against local knowledge and perceptions. This geographical bias may also be linked to the more prominent presence of small-scale societies in Africa, Asia, and the Arctic, although this does not explain the relatively numerous studies in South America. The Arctic, in turn, plays an interesting role as it represents one of the few areas where indigenous peoples and local resource-dependent communities exist within highly developed countries with capacity to perform high quality interdisciplinary and transdisciplinary studies.

There may also be a link to why researchers go about studying local perceptions of GEC in the first place. While some researchers may undertake such studies with the main purpose being to fill data gaps (assuming that LK has a certain validity, at least concerning local, observational data), others may have the primary aim of testing or proving the validity of LK. Another reason may be the aim of identifying new research areas or questions, which implies that LK is seen as valid per se. That said, many scholars might intentionally dismiss LK precisely because it is integrative, and thus difficult for disciplinary thinkers to understand and manage. While there may be good reasons to undertake coproduction of knowledge and transdisciplinary studies (e.g., more suited to address complex systems, more democratic knowledge production, better-placed solutions), the disciplinary structure of academic knowledge production, the lack of resources, and closed and competitive career paths for scientists all act as barriers to perform more integrative research (Nowotny et al. 2001, Hirsch Hadorn et al. 2006, Cornell et al. 2013). Finally, there may be practical considerations such as improving adaptation, mitigation, or communication strategies in relation to GEC, in which case the validity of LK might not be of prime importance, but rather the assumption that LK influences people's behavior and therefore needs to be taken into account. This might explain why, of our three thematic foci, adaptive strategies were more commonly addressed in the reviewed articles than were factors of cognitive psychology or ontologies.

\section{Philosophical questions}

This brings us to the complexity of GEC research: both scale and causality are hugely complex phenomena that scientific research continues to be challenged by. Yet, the concept of scale might be over-dichotomized, especially when categorized as simply "local" or "global," and as largely portrayed in the current GEC discourse. As our findings illustrate, there are a number of gaps in the current GEC research in terms of scale and causality, resulting in little evidence of how local societies perceive concepts of scale (e.g., "global" or "local") and the possible interactions between scales.

Scale is also strongly linked with models of causation (i.e., to cultural perceptions of drivers of change), as there is undoubtedly a feedback continuum across scales and perceptions. Aspects of GEC might well be changing ways of life and associated value, which might in turn influence local perception (Turner et al. 2008, Byg and Salick 2009). One might also ask to what extents are changing values simply adaptations to change, especially in intergenerational time frame? Similarly, it is extremely difficult to tease apart the political, cultural, social, and economic factors that influence perception, and how these factors might influence what people perceive (or state) as the reasons for change. The same can be said for psychological factors, although studies in phenomena such as the Shifting Baselines Syndrome have already shed some light on how these impact local perceptions of environmental change (see Fernández-Llamazares et al. 2015b).

The concept of change is also something that we argue needs to be considered from a cultural and ontological perspective (Barnes et al. 2013). In many cosmologies, the world is not seen as static, and longer cycles may be recognized and passed on in oral tradition over generations. The implications of this are related to those of psychological phenomena in that perceptions captured at the individual and time-specific levels may vary greatly depending on the positioning against larger perceived cycles and/ or the knowledge held of broader patterns of change. Such change is not necessarily associated with "climate change" or other scientific phenomena as Western science frames them, but rather explained according to spiritual beliefs. Similarly, if a local population is experiencing the same environmental phenomena but with more frequency or extremes, it may not necessarily change its beliefs or perceptions of the drivers of these. Further research - especially from more interpretive rather than positivist disciplines (see Hulme 2011) _ could shed light on the multiple nonscientific ways in which people perceive and interpret change.

As for the impacts of GEC, and whether they are seen as positive or negative, our results gave no cases of changes that were seen as solely positive. While it may well be that local small-scale communities really are the net losers of GEC (hence, their attitudes), there may also be a tendency of local people to emphasize the negative; e.g., in the hope of receiving assistance, even when livelihoods have actually improved. The negative perceptions may also be related to the ever more unpredictable nature of GEC; hence, a source of insecurity. Whatever the reasons, they are unlikely to be so clear-cut. For instance, the perception of negative effects linked to environmental change may in some cases be partially offset by the benefits that may result from certain change, as seen in the case of oil exploitation in northwestern Siberia providing new market opportunities for 
reindeer herders, despite environmental degradation (Forbes et al. 2009). Therefore, while scientists tend to focus on negative impacts of GEC, local populations' perceptions may be very different when it comes to impacts on their livelihoods. This calls for a deepened ontological approach to understanding the concept of change; e.g., through more indepth qualitative studies and opening of knowledge systems. As Denzin and Lincoln (2000) concur, contemporary research is becoming more inclusive of different worldviews, and other "ways of knowing" are central to this evolving qualitative discourse.

That said, there are many challenges related to gathering and presenting LK and integrating it into Western scientific research. These can be seen as trade-offs or even inherent tensions between (i) a commitment to ethical principles and performing "decolonized" science (e.g., Tuhiwai Smith 1999) on the one hand, and (ii) following the expectations or established rules imposed by academia on the other. These relate not only to research design and methods, but also to the eventual distribution of benefits of the research findings. Similarly, the ontological and epistemic characteristics of both local and scientific knowledge can become an impediment to a common and merged body of theory, especially if practical use of knowledge by local people is to be enabled. As mentioned, agents make decisions (e.g., on the use of natural resources) based on individual perceptions rather than on measured variables or more diagnosed criteria (Oba and Kotile 2001, Maule and Hodgkinson 2002, Voyer et al. 2012). Moreover, small-scale societies often rely on many different kinds and systems of knowledge in their daily interactions with the environment (Brant-Castellano 2000). This has important implications on the relationships between local and scientific knowledge (Agrawal 1995, Ingold 2000), especially if and when LK cannot be measured or quantified, and thus continues to be largely dismissed by Western researchers, stemming from a different appreciation regarding the truthful representation of the world by these two epistemological systems (Johnson and Murton 2007).

\section{Methodological caveats}

There are a number of methodological challenges and limitations to our study that are important to point out. Already in the actual material reviewed, there are potential sources of bias derived from having included only journal articles in our sample - as opposed to books or book chapters - particularly as the latter tend to be of a more ethnographic nature, which arguably is what accounts of LK entail. Another significant limitation is that, in general, the articles we reviewed gave very little methodological explanation or description, which makes it difficult for readers to discern between what is reported by each study as being a local perception and what the individual's (or community's) actual perceptions are. This is an important methodological caveat given that how questions are designed may have significant effects on the answers given.

This brings us to a question of unit and representation; i.e., whether the results presented in the studies reviewed really can be generalized as "local," or whether there might be significant heterogeneity in response (and perception) within a community. This question of possible heterogeneity in local perceptions remains for the most part unacknowledged in the literature on GEC, while the literature on intracultural variations of LK suggests that such a heterogeneity is very likely (Begossi et al. 2002, Ghimire et al. 2005). There may also be a tendency for scientists to use hegemonic approaches and skew their results in an attempt to force a certain logic; e.g., to report more homogenous views on local perceptions in order to make their scientific arguments come across as more solid or credible. Additionally, there is the possibility that what external scientists understand as "local" or "global" (be it knowledge, responses, strategies, for example) may not necessarily be seen or selfperceived as such by local people themselves.

There are also possible confirmation biases and gaps in understanding causation when people are asked questions based on external (predefined) terms and frameworks. Simply the asking of change from people who may or may not perceive any change may create a bias in the results. Hence, there may be some bias in the results due to local respondents having given strategic answers. In general, studies like the ones we have reviewed here are almost always framed according to Western scientific logic, meaning that even the use of categories (such as "local" versus "global") are predefined and may go contrary to local framings and epistemologies (Aswani and Lauer 2014). This might not only influence the responses given, but may also leave out important and relevant aspects of research that go unnoticed as scientists remain limited by their own epistemological thinking. What we draw from these limitations is a call for more indepth, qualitative studies to better complement the more common inbreadth, quantitative ones.

\section{Suggestions for future research}

The current literature begs for a conjunction of research on livelihoods and GEC (although these may be more common in the vulnerability literature). For instance, studies on whether groups with different livelihood strategies perceive change differently are called for, as are studies that addres the universality of GEC perceptions and cognition, and whether these might be useful in distinguishing diversity. With regard to appropriate units of scale, and addressing the above-mentioned questions on possible intracommunity heterogeneity in the evaluation of a change, association of a change with a cause, and preferences for responses, future research would do well in considering a shift in the focus of unit of analysis. For instance, a shift from communitylevel analysis down to the household level could be more appropriate. As demonstrated by von Glasenapp and Thornton (2011), the household is a suitably "small flexible unit" (Netting 1993, as cited in von Glasenapp and Thornton 2011) and a repository of LK and components of resilience.

Finally, more cross-cultural research is needed, as is the need to include a much more embedded perspective that encompasses embodied experiences in the study of knowledge and perception. Measuring (or discovering) perception can be resource costly. One way to overcome this is to look at the responses and ask-in hindsight - what made people do what they chose to do, or say what they said, or perceive what they reported to perceive. We agree with Ribot (2011) and others (cf. Cameron 2012) who argue that current approaches used in GEC research are far too narrow to encompass the complexity they involve, as research must not simply identify who and what is vulnerable to environmental change, but also why. When designing protocols on what to ask and how, and what kind of knowledge to capture (such as 
experiential knowledge in relation to certain kinds of change), the value of questions that address the "why" behind local perceptions and explanations should not be underestimated.

\section{CONCLUSION}

Our study confirms previous studies (Barnes et al. 2013, Castree et al. 2014), suggesting that most research on GEC has not to date relied on local perceptions and understandings, despite their importance as a resource for adaptive capacity (Naess 2013). The relatively little research that does exist remains fragmentary, geographically scattered, and mainly qualitative (ISSC and UNESCO 2013). We also found that researchers integrate vernacular understandings of environmental change in very heterogeneous ways due to the absence of clear standards on how to do so. The use of categories based on formal science-while collecting data on local perceptions of environmental changeis prevalent in the literature, which runs the risk of biasing the actual perceived changes at the local level with imposed Western epistemological frameworks that are disconnected from particular cultural contexts. We as researchers should therefore be aware of the effects that enforcing our own hegemonic logical frameworks and epistemologies may have on the responses and results we obtain, especially when carrying out cross-cultural research. The same applies to preconceived responses or results, even when it implies compromising on clarity or strength of our scientific arguments. If we wish to inform and engage in the facilitation of adaptive processes to better mitigate and cope with GEC, then the different (including moral) causations held by local peoples may be critical in defining success. Our work as external researchers also calls not only for community-specific validation of results and knowledge, but for increased coproduction of hybrid knowledge, if we are to decolonize what remains as a highly top-down system of scientific practice in framing GEC research.

In attempting to decolonize research-e.g., by means of codesign and increased facilitation-problems may well arise if simultaneously trying to standardize approaches more broadly. These challenges are not new to researchers, as already noted by several scholars (Agrawal 1995, Ingold 2000, Nowotny et al. 2001, Hirsch Hadorn et al. 2006, Cornell et al. 2013), who point out that, in addition to bridging knowledge systems and decolonizing scientific methods, there is a need to complement quantitativebreadth-type studies (which enable comparability) with qualitative-depth ones (for increased acknowledgment and respect for the cultural diversity of concepts and interpretations). Whether and how these seemingly contradictory objectives can be successfully merged remains to be seen, and certainly calls for further research in itself. In the meantime, introducing local worldviews into the theoretical process can provide for a more inclusive perspective on the concept of knowledge and its production. Similarly, the encounter of seemingly contrasting worldviews can be used to create an "ethical space" (Poole 1972): a place between worldviews where the intentions of each are submitted for negotiation. This in turn can open up the possibility for configuring new models of research and knowledge production that are mutually developed through negotiation and respect in cross-cultural interaction (Ermine et al. 2004). Such processes are by no means easy, and may well entail a ceding of control and re-orientation in thinking (Nicholls 2009, Coram 2011) or a shift altogether in paradigmatic approach, thereby allowing for a much closer attention to the vernacular, and dynamic understanding of scale and context (Grandia 2015).
While we do not have all the answers on how to go about improving GEC research on local perceptions, what is clear is that both the qualitative indepth and the quantitative inbreadth approaches play a critical and complementary role in research on local perceptions of GEC. Despite this, our study found that (i) very few studies in the broader GEC research deal with local perceptions overall, (ii) the methods employed in GEC research remain largely underreported and inconsistent, and (iii) very few studies go into sufficient depth in addressing issues of knowledge coproduction, or ontological/epistemic aspects of GEC perceptions. We therefore call for the further development of a meta-language around adaptation, perception, and mediation so that we can begin to appreciate and understand the diversity around these phenomena across multiple scales. We urge future researchers to consider their possible contribution toward such a meta-language when designing their studies in order to improve comparability among cases and broader understandings of the interaction of perception and adaptation processes and pathways among human societies. Again, combining standardized approaches with decolonized ones brings with it new challenges, but by following the road maps already laid out by scholars in this area (e.g., Cornell et al. 2013), it may well be feasible.

Incorporating and better understanding local perceptions of GEC requires addressing the "why?" behind perceptions and explanations. Only in getting a deeper understanding can we perhaps begin to explain why people react to environmental changes the way they do, and thereby be better placed to work on longer term adaptation and mitigation strategies to GEC, among other alternative solutions to current environmental problems. Such analysis would also improve communication, relations, and deliberative processes among actors, and provide support for suitable adaptation measures at appropriate scales.

\section{Responses to this article can be read online at: http://www.ecologyandsociety.org/issues/responses. $\mathrm{php} / 8482$}

\section{Acknowledgments:}

We would like to thank ICREA for providing us with financial support to organize a workshop around which the authors of this paper could meet in person to work on this paper. A. Pyhälä and Á. Fernández-Llamazares acknowledge financial support from the European Union's Seventh Framework Programme (FP7/2007-2013)I ERC grant agreement $n r$. FP7-261971-LEK, and M. Salpeteur from the Simulpast project (CSD2010-00034) funded by the Spanish MINECO under the 2010 CONSOLIDER-INGENIO program. Many thanks also to V. Reyes-García, J. Erlandson, and $J$. Salick, who provided useful comments at earlier stages of the study.

\section{LITERATURE CITED}

Adams, W. M. 2007. Thinking like a human: social science and the two cultures problem. Oryx 41(3):275-276.

Adger, W. N., N. W. Arnell, and E. L. Tompkins. 2005. Successful adaptation to climate change across scales. Global Environmental Change 15(2):77-86. http://dx.doi.org/10.1016/j.gloenvcha.2004.12.005 
Agrawal, A. 1995. Dismantling the divide between indigenous and scientific knowledge. Development and Change 26(3):413439. http://dx.doi.org/10.1111/j.1467-7660.1995.tb00560.x

Agrawal, A. 2008. The role of local institutions in adaptation to climate change. World Bank, Social Development Department, Washington, D.C., USA.

Agrawal, A. 2010. Local institutions and adaptation to climate change. In R. Mearns and A. Norton, editors. Social dimension of climate change. Equity and vulnerability in a warming world. The World Bank, Washington, D.C., USA.

Ainsworth, C. H., T. J. Pitcher, and C. Rotinsulu. 2008. Evidence of fishery depletions and shifting cognitive baselines in Eastern Indonesia. Biological Conservation 141(3):848-859.

Alessa, L. N., A. A. Kliskey, P. Williams, and M. Barton. 2008. Perception of change in freshwater in remote resource-dependent Arctic communities. Global Environmental Change 18:153-164. http://dx.doi.org/10.1016/j.gloenvcha.2007.05.007

Anik, S. I., and M. A. S. A. Khan. 2012. Climate change adaptation through local knowledge in the north eastern region of Bangladesh. Mitigation and Adaptation Strategies for Global Change 17:879-896. http://dx.doi.org/10.1007/s11027-011-9350-6

Aswani, S., and M. Lauer. 2014. Indigenous people's detection of rapid ecological change. Conservation Biology 28(3):820-828. http://dx.doi.org/10.1111/cobi.12250

Barnes, J., M. Dove, M. Lahsen, A. Mathews, P. McElwee, R. McIntosh, F. Moore, J. O'Reilly, B. Orlove, R. Puri, H. Weiss, and K. Yager. 2013. Contribution of anthropology to the study of climate change. Nature Climate Change 3:541-544. http://dx.doi. org/10.1038/nclimate1775

Barnosky, A. D., E. A. Hadly, J. Bascompte, E. L. Berlow, J. H. Brown, M. Fortelius, W. M. Getz, J. Harte, A. Hastings, P. A,. Marquet, N. D. Martinez, A. Mooers, P. Roopnarine, G. Vermeij, J. W. Williams, R. G. Gillespie, J. Kitzes, C. Marshall, N. Matzke, D. P. Mindell, E. Revilla, and A. B. Smith. 2012. Approaching a state shift in Earth's biosphere. Nature 486(7401):52-58. http:// dx.doi.org/10.1038/nature11018

Begossi, A., N. Hanazaki, and J. Y. Tamashiro. 2002. Medicinal plants in the Atlantic forest (Brazil): knowledge, use, and conservation. Human Ecology 30(3):281-299. http://dx.doi. org/10.1023/A:1016564217719

Below, T. B., K. D. Mutabazi, D. Kirschke, C. Franke, S. Sieber, R. Siebert, and K. Tscherning. 2012. Can farmers' adaptation to climate change be explained by socio-economic household-level variables? Global Environmental Change 22:223-235. http://dx. doi.org/10.1016/j.gloenvcha.2011.11.012

Berkes, F. 1999. Sacred ecology: traditional ecological knowledge and resource management. Taylor and Francis, Philadelphia, USA and London, UK.

Berkes, F. 2009. Indigenous ways of knowing and the study of environmental change. Journal of the Royal Society of New Zealand 39(4):151-156. http://dx.doi.org/10.1080/03014220909510568

Boillat, S., and F. Berkes. 2013. Perception and interpretation of climate change among Quechua farmers of Bolivia: indigenous knowledge as a resource for adaptive capacity. Ecology and Society 18(4):21. http://dx.doi.org/10.5751/es-05894-180421

Boissière, M., B. Locatelli, D. Sheil, M. Padmanaba, and E. Sadjudin. 2013. Local perceptions of climate variability and change in tropical forests of Papua, Indonesia. Ecology and Society 18(4):13. http://dx.doi.org/10.5751/es-05822-180413

Brant-Castellano, M. 2000. Updating Aboriginal traditions of knowledge. In G. J. Sefa Dei, B. L. Hall, and D. Goldin-Rosenberg, editors. Indigenous knowledge in global contexts: multiple readings of our world. University of Toronto Press, Toronto, Ontario, Canada.

Bridges, K. W., and W. C. McClatchey. 2009. Living on the margin: ethnoecological insights from Marshall Islanders at Rongelap atoll. Global Environmental Change 19:140-146. http://dx.doi. org/10.1016/j.gloenvcha.2009.01.009

Brooks, N., W. N. Adger, and P. M. Kelly. 2005. The determinants of vulnerability and adaptive capacity at the national level and the implications for adaptation. Global Environmental Change 15:151-163. http://dx.doi.org/10.1016/j.gloenvcha.2004.12.006

Brosius, J. P. 1999. Analyses and interventions; anthropological engagements with environmentalism. Current Anthropology 40:277-309.

Bunce, M., L. Mee, L. D. Rodwell, and R. Gibb. 2009. Collapse and recovery in a remote small island's tale of adaptive cycles or downward spirals? Global Environmental Change 19:213-226. http://dx.doi.org/10.1016/j.gloenvcha.2008.11.005

Bunce, M., L. D. Rodwell, R. Gibb, and L. Mee. 2008. Shifting baselines in fishers' perceptions of island reef fishery degradation. Ocean \& Coastal Management 51:285-302. http://dx.doi. org/10.1016/j.ocecoaman.2007.09.006

Bunce, M., S. Rosendo, and K. Brown. 2010. Perceptions of climate change, multiple stressors and livelihoods on marginal African coasts. Environment, Development and Sustainability 12:407-440. http://dx.doi.org/10.1007/s10668-009-9203-6

Burton, I., S. Huq, B. Lim, O. Pilifosova, and E. L. Schipper. 2002. From impacts assessment to adaptation priorities: the shaping of adaptation policy. Climate Policy 3:24-41. http://dx.doi. org/10.1016/s1469-3062(02)00038-4

Byg, A., and J. Salick. 2009. Local perspectives on a global phenomenon. Climate change in Eastern Tibetan villages. Global Environmental Change 19:156-166. http://dx.doi.org/10.1016/j. gloenvcha.2009.01.010

Cameron, E. S. 2012. Securing indigenous politics: a critique of the vulnerability and adaptation approach to the human dimensions of climate change in the Canadian Arctic. Global Environmental Change 22(1):103-114. http://dx.doi.org/10.1016/ j.gloenvcha.2011.11.004

Capstick, S., L. Whitmarsh, W. Poortinga, N. Pidgeon, and P. Upham. 2014. International trends in public perceptions of climate change over the past quarter century. WIREs Climate Change 6:35-61. http://dx.doi.org/10.1002/wcc.321

Castree, N., W. M. Adams, J. Barry, D. Brockington, B. Buscher, E. Corbera, D. Demeritt, R. Duffy, U. Felt, K. Neves, P. Newell, 
L. Pellizzoni, K. Rigby, P. Robbins, L. Robin, D. B. Rose, A. Ross, D. Schlosberg, S. Sorlin, P. West, M. Whitehead, and B. Wynne. 2014. Changing the intellectual climate. Nature Climate Change 4(9):763-768. http://dx.doi.org/10.1038/nclimate2339

Combest-Friedman, C., P. Christie, and E. Miles. 2012. Household perceptions of coastal hazards and climate change in the Central Philippines. Journal of Environmental Management 112:137-148. http://dx.doi.org/10.1016/j.jenvman.2012.06.018

Coram, S. 2011. Rethinking indigenous research approval: the perspective of a 'stranger'. Qualitative Research Journal 11(2):3847. http://dx.doi.org/10.3316/qrj1102038

Cornell, S., F. Berkhout, W. Tuinstra, J. D. Tàbara, J. Jäger, I. Chabay, B. de Wit, R. Langlais, D. Mills, P. Moll, I. M. Otto, A. Petersen, C. Pohl, and L. van Kerkhoff. 2013. Opening up knowledge systems for better responses to global environmental change. Environmental Science \& Policy 28:60-70. http://dx.doi. org/10.1016/j.envsci.2012.11.008

Cox, K. R. 1997. Spaces of globalization. Guilford, New York, USA.

Cruikshank, J. 2001. Glaciers and climate change: perspectives from oral tradition. Arctic 54(4):377-393. http://dx.doi. org/10.14430/arctic795

Crutzen, P. J. 2002. The “anthropocene.” Journal de Physique IV 12(10):1-5. http://dx.doi.org/10.1051/jp4:20020447

Crutzen, P. J., and W. Steffen. 2003. How long have we been in the Anthropocene era? Climatic Change 61:251-257. http://dx. doi.org/10.1023/B:CLIM.0000004708.74871.62

Davis, A., and J. R. Wagner. 2003. Who knows? On the importance of identifying "experts" when researching local ecological knowledge. Human Ecology 31:463-489. http://dx.doi.org/10.1023/ A:1025075923297

Daw, T. M. 2010. Shifting baselines and memory illusions: What should we worry about when inferring trends from resource user interviews? Animal Conservation 13(6):534-535. http://dx.doi. org/10.1111/j.1469-1795.2010.00418.X

Denzin, N. K., and Y. S. Lincoln, editors. 2000. Handbook of qualitative research. Second edition. Sage, Thousand Oaks, California, USA.

Deressa, T. T., R. M. Hassan, C. Ringler, T. Alemu, and M. Yesuf. 2009. Determinants of farmers' choice of adaptation methods to climate change in the Nile Basin of Ethiopia. Global Environmental Change 19(2):248-255. http://dx.doi.org/10.1016/ j.gloenvcha.2009.01.002

Deryungina, T. 2012. How do people update? The effects of local weather fluctuations on beliefs about global warming. Climatic Change 118(2):397-416. http://dx.doi.org/10.1007/s10584-012-0615-1

Descola, P. 2005. Beyond nature and culture. University of Chicago Press, Chicago, Illinois, USA.

Dirzo, R., H. S. Young, M. Galetti, G. Ceballos, N. J. B. Isaac, and B. Collen. 2014. Defaunation in the Anthropocene. Science 345(6195):401-406. http://dx.doi.org/10.1126/science.1251817

Dove, M. R., D. S. Smith, M. T. Campos, A. S. Matthews, A. Rademacher, S. Rhee, and L. M. Yoder. 2007. Globalisation and the construction of western and non-western knowledge. In P. Sillitoe, editor. Local science vs. global science: approaches to indigenous knowledge in international development. Berghahn, New York, USA and Oxford, UK.

Doyle, J. 2009. Seeing the climate? The problematic status of visual evidence in climate change campaigning. Pages 279-298 in S. I. Dobrin and S. Morey, editors. Ecosee: image, rhetoric, nature. First edition. SUNY Press.

Egan, P. J., and M. Mullin. 2014. Local weather and climate concern. Nature Climate Change 4:89-90. http://dx.doi. org/10.1038/nclimate2104

Engels, A., O.. Hüther, M. Schäfer, and H. Held. 2013. Public climate-change skepticism, energy preferences and political participation. Global Environmental Change 23:1018-1027. http:// dx.doi.org/10.1016/j.gloenvcha.2013.05.008

Erlandson, J. M. 2012. As the world warms: rising seas, coastal archaeology, and the erosion of maritime history. Journal of Coastal Conservation 16:137-142. http://dx.doi.org/10.1007/ $\underline{\mathrm{s} 11852-010-0104-5}$

Ermine, W., R. Sinclair, and B. Jeffery. 2004. The ethics of research involving indigenous peoples. IPHRC, Saskatchewan, Canada.

Fernández-Llamazares, Á., I. Díaz-Reviriego, A. C. Luz, M. Cabeza, A. Pyhälä, and V. Reyes-García. 2015b. Rapid ecosystem change challenges the adaptive capacity of Local Environmental Knowledge. Global Environmental Change 31:272-284. http://dx. doi.org/10.1016/j.gloenvcha.2015.02.001

Fernández-Llamazares, Á., M. E. Méndez-López, I. DíazReviriego, M. F. McBride, A. Pyhälä, A. Rosell-Melé, and V. Reyes-García. 2015a. Links between media communication and local perceptions of climate change in an indigenous society. Climatic Change 131:307-320. http://dx.doi.org/10.1007/ $\underline{\text { s10584-015-1381-7 }}$

Forbes, B. C., F. Stammler, T. Kumpula, N. Meschtyb, A. Pajunen, and E. Kaarlejärvi. 2009. High resilience in the Yamal-Nenets social-ecological system, West Siberian Arctic, Russia. Proceedings of the National Academy of Sciences 106(52):2204122048. http://dx.doi.org/10.1073/pnas.0908286106

Ford, J. D., B. Smit, and J. Wandel. 2006. Vulnerability to climate change in the Arctic: a case study from Arctic Bay, Canada. Global Environmental Change 16:145-160. http://dx.doi.org/10.1016/j. gloenvcha.2005.11.007

Gearheard, S., M. Pocernich, R. Stewart, J. Sanguya, and H. P. Huntington. 2010. Linking Inuit knowledge and meteorological station observations to understand changing wind patterns at Clyde River, Nunavut. Climatic Change 100(2):267-294. http:// dx.doi.org/10.1007/s10584-009-9587-1

Ghimire, S., D. McKey, and Y. Aumeeruddy-Thomas. 2005. Heterogeneity in ethnoecological knowledge and management of medicinal plants in the Himalayas of Nepal: implications for conservation. Ecology and Society 9(3):6.

Grandia, L. 2015. Slow ethnography: a hut with a view. Critique of Anthropology 35(3):301-317. http://dx.doi.org/10.1177/03082$\underline{75 \times 15588616}$ 
Green, D., J. Billy, and A. Tapim. 2010. Indigenous Australians' knowledge of weather and climate. Climatic Change 100:337-354. http://dx.doi.org/10.1007/s10584-010-9803-Z

Gupta, A. K. 1999. Rewarding creativity for conserving diversity in the Third World: Can IPR regime serve the needs of contemporary and traditional knowledge experts and communities in the Third World? Pages 119-129 in T. Cottier, P. Widmer, and K. Schindler, editors. Strategic issues of IP management in a globalizing economy. Hart Publishing, Oxford, UK.

Habiba, U., R. Shaw, and Y. Takeuchi. 2012. Farmer's perception and adaptation practices to cope with drought: perspectives from northwestern Bangladesh. International Journal of Disaster Risk Reduction 1:72-84. http://dx.doi.org/10.1016/j.ijdrr.2012.05.004

Helgeson, J., S. van der Linden, and I. Chabay. 2012. The role of knowledge, learning and mental models in perceptions of climate change related risks. In A. Wals and P. B. Corcoran, editors. Learning for sustainability in times of accelerating change. Wageningen Academic Publishers, Wagenigen, The Netherlands. http://dx.doi.org/10.3920/978-90-8686-757-8 21

Henrich, J., S. J. Heine, and A. Norenzayan. 2010. Most people are not WEIRD. Nature 466:29. http://dx.doi.org/10.1037/14805-007

Hirsch Hadorn, G., D. Bradley, C. Pohl, S. Rist, and U. Wiesmann. 2006. Implications of transdisciplinarity for sustainability research. Ecological Economics 60(1):119-128. http://dx.doi.org/10.1016/j.ecolecon.2005.12.002

Howe, P. D., and A. Leiserowitz. 2013. Who remembers a hot summer or a cold winter? The asymmetric effect of beliefs about global warming on perceptions of local climate conditions in the U.S. Global Environmental Change 23(6):1488-1500. http://dx. doi.org/10.1016/j.gloenvcha.2013.09.014

Howe, P. D., E. M. Markowitz, T. M. Lee, C. Y. Ko, and A. Leiserowitz. 2012. Global perceptions of local temperature change. Nature Climate Change 3:352-356. http://dx.doi. org/10.1038/nclimate1768

Hulme, M. 2011. Meet the humanities. Nature Climate Change 1:177-179. http://dx.doi.org/10.1038/nclimate1150

Ignatowski, J. A., and J. Rosales. 2013. Identifying the exposure of two subsistence villages in Alaska to climate change using traditional ecological knowledge. Climatic Change 121:285-299. http://dx.doi.org/10.1007/s10584-013-0883-4

Ingold, T. 2000. The perception of the environment. Essays in livelihood, dwelling and skill. Routledge, London, UK and New York, USA. http://dx.doi.org/10.4324/9780203466025

International Geosphere-Biosphere Programme (IGBP). 2004. Global change and the earth system. A planet under pressure. Springer, New York, USA.

Intergovernmental Panel on Climate Change (IPCC). 2007. Climate change 2007: synthesis report. Contribution of Working Groups I, II and III to the Fourth Assessment Report of the IPCC. R. K. Pachauri and A. Reisinger, editors. IPCC, Geneva, Switzerland.
International Social Science Council (ISSC) and United Nations Educational, Scientific and Cultural Organization (UNESCO). 2013. World social science report, changing global environments. OECD Publishing and UNESCO Publishing, Paris, France.

Johnson, J. T., and B. Murton. 2007. Re/placing native science: indigenous voices in contemporary constructions of nature. Geographical Research 45(2):121-129 http://dx.doi.org/10.1111/ j.1745-5871.2007.00442.x

Kahn, P. H. 2002. Children's affiliations with nature: structure, development, and the problem of environmental generational amnesia. In P. H. Kahn and S. R. Kellert, editors. Children and nature: psychological, sociocultural, and evolutionary investigations. MIT Press, Cambridge, Massachusetts, USA.

Kansiime, M. K., S. K. Wambugu, and C. A. Shisanya. 2013. Perceived and actual rainfall trends and variability in eastern Uganda: implications for community preparedness and response. Journal of Natural Sciences Research 3(8):179-194.

King, D. N. T., J. Goff, and A. Skipper. 2007. Maori environmental knowledge and natural hazards in Aotearoa-New Zealand. Journal of the Royal Society of New Zealand 37(2):59 73. http://dx.doi.org/10.1080/03014220709510536

Kottak, C. P. 1999. The new ecological anthropology. American Anthropologist 101:23"35. http://dx.doi.org/10.1525/aa.1999.101.1.23

Laidler, G. J. 2006. Inuit and scientific perspectives on the relationship between sea ice and climate: the ideal complement? Climatic Change 78:407-444. http://dx.doi.org/10.1007/s10584-006-9064$\underline{z}$

Lakoff, G. 2010. Why it matters how we frame the environment. Environmental Communication 4(1):70-81. http://dx.doi. org/10.1080/17524030903529749

Lauer, M., and S. Aswani. 2010. Indigenous knowledge and longterm ecological change: detection, interpretation, and responses to changing ecological conditions in Pacific Island communities. Environmental Management 45:985-997. http://dx.doi.org/10.1007/ $\underline{\mathrm{s} 00267-010-9471-9}$

Leduc, T. B. 2006. Inuit economic adaptations for a changing global climate. Ecological Economics 60:27-35. http://dx.doi. org/10.1016/j.ecolecon.2006.02.004

Leonti, M. 2011. The future is written: impact of scripts on the cognition, selection, knowledge and transmission of medicinal plant use and its implications for ethnobotany and ethnopharmacology. Journal of Ethnopharmacology 134(3):542555. http://dx.doi.org/10.1016/j.jep.2011.01.017

Li, T. M. 2007. The will to improve: governmentality, development, and the practice of politics. Duke University Press, Durham, North Carolina, USA. http://dx.doi.org/10.1215/9780822389781

Li, C., Y. Tang, H. Luo, B. Di, and L. Zhang. 2013. Local farmers' perceptions of climate change and local adaptive strategies: a case study from the Middle Yarlung Zangbo River Valley, Tibet, China. Environmental Management 52:894-906. http://dx.doi. org/10.1007/s00267-013-0139-0 
Lykke, A. M., M. K. Kristensen, and S. Ganaba. 2004. Valuation of local use and dynamics of 56 woody species in the Sahel. Biodiversity \& Conservation 13:1961-1990. http://dx.doi. org/10.1023/B:BIOC.0000035876.39587.1a

Manandhar, S., D. S. Vogt, S. R. Perret, and F. Kazama. 2011. Adapting cropping systems to climate change in Nepal: a crossregional study of farmers' perception and practices. Regional Environmental Change 11(2):335-348.

Marin, A. 2010. Riders under storms: contributions of nomadic herders' observations to analysing climate change in Mongolia. Global Environmental Change 20:162-176. http://dx.doi. org/10.1016/j.gloenvcha.2009.10.004

Marin, A., and F. Berkes. 2012. Local people's accounts of climate change: to what extent are they influenced by the media? WIRES Climate Change 4(1):1-8. http://dx.doi.org/10.1002/wcc.199

Maule, A. J., and G. P. Hodgkinson. 2002. Heuristics, biases and strategic decision making. Psychologist 15(2):68-71.

Meze-Hausken, E. 2004. Contrasting climate variability and meteorological drought with perceived drought and climate change in northern Ethiopia. Climate Research 27:19-31. http:// dx.doi.org/10.3354/cr027019

Monastersky, R. 2009. International polar year: the social pole? Nature 457:1077-1078. http://dx.doi.org/10.1038/4571077a

Mormont, M., and C. Dasnoy. 1995. Source strategies and the mediatization of climate change. Media, Culture \& Society 17:4964. http://dx.doi.org/10.1177/016344395017001004

Myers, T. A., E. W. Maibach, C. Roser-Renouf, K. Akerlof, and A. A. Leiserowitz. 2013. The relationship between personal experience and belief in the reality of global warming. Nature Climate Change 3:343-347. http://dx.doi.org/10.1038/nclimate1754

Nadasdy, P. 2007. The gift in the animal: the ontology of hunting and human-animal sociality. American Ethnologist 34(1):25-43. http://dx.doi.org/10.1525/ae.2007.34.1.25

Naess, L. O. 2013. The role of local knowledge in adaptation to climate change. WIREs Climate Change 4(2):99-106. http://dx. doi.org/10.1002/wcc.204

Nazarea, V. 1999. Ethnoecology: situated knowledgellocated lives. University of Arizona Press, Tucson, Arizona, USA.

Newsham, A. J., and D. S. G. Thomas. 2011. Knowing, farming and climate change adaptation in North-Central Namibia. Global Environmental Change 21:761-770. http://dx.doi.org/10.1016/j. gloenvcha.2010.12.003

Nicholls, R. 2009. Research and indigenous participation: critical reflexive methods. International Journal of Social Research Methodology 12(2):117-126. http://dx.doi.org/10.1080/1364557$\underline{0902727698}$

Nkomwa, E. C., M. Kalanda-Joshua, C. Ngongondo, M. Monjerezi, and F. Chipungu. 2014. Assessing indigenous knowledge systems and climate change adaptation strategies in agriculture: a case study of Chagaka Village, Chikhwawa, Southern Malawi. Physics and Chemistry of the Earth 67-69:164172. http://dx.doi.org/10.1016/j.pce.2013.10.002
Nowotny, H., P. Scott, and M. Gibbons. 2001. Re-thinking science: knowledge and the public in an age of uncertainty. John Wiley and Sons.

Oba, G., and D. G. Kotile. 2001. Assessments of landscape level degradation in southern Ethiopia: pastoralists versus ecologists. Land Degradation \& Development 12(5):461-475. http://dx.doi. org/10.1002/ldr.463

Oldekop, J. A., A. J. Bebbington, N. K. Truelove, G. Holmes, S. Villamarín, and R. F. Preziosi. 2012. Environmental impacts and scarcity perception influence local institutions in indigenous Amazonian Kichwa communities. Human Ecology 40:101-115. http://dx.doi.org/10.1007/s10745-011-9455-2

Orlove, B., J. Chiang, and M. Cane. 2002. Ethnoclimatology in the Andes: a cross-disciplinary study uncovers a scientific basis for the scheme Andean potato farmers traditionally use to predict the coming rains. American Scientist 90(5):428-435. http://dx.doi. org/10.1511/2002.33.791

Orlove, B., C. Roncoli, M. Kabugo, and A. Majugu. 2010. Indigenous climate knowledge in southern Uganda: the multiple components of a dynamic regional system. Climatic Change 100 (2):243-265.

Papworth, S. K., J. Rist, L. Coad, and E. J. Milner-Gulland. 2009. Evidence for shifting baseline syndrome in conservation. Conservation Letters 2:93-100. http://dx.doi.org/10.1111/ j.1755-263x.2009.00049.x

Patt, A. G., and D. Schröter. 2008. Perceptions of climate risk in Mozambique: implications for the success of adaptation strategies. Global Environmental Change 18:458-467. http://dx. doi.org/10.1016/j.gloenvcha.2008.04.002

Patt, A. G., and E. U. Weber. 2014. Perceptions and communication strategies for the many uncertainties relevant for climate policy. WIREs Climate Change 5:219-232. http://dx.doi. org/10.1002/wcc. 259

Petheram, L., K. K. Zander, B. M. Campbell, C. High, and N. Stacey. 2010. 'Strange changes': indigenous perspectives of climate change and adaptation in NE Arnhem Land (Australia). Global Environmental Change 20(4):681-692. http://dx.doi. org/10.1016/j.gloenvcha.2010.05.002

Poole, R. 1972. Towards deep subjectivity. Harper \& Row, New York, USA.

Rai, J. K. 2010. Global and local discourses on climate change: a perspective from the concept of embeddedness. Dhaulagiri Journal of Sociology and Anthropology 4:143-180.

Reo, N. J., and K. P. Whyte. 2012. Hunting and morality as elements of traditional ecological knowledge. Human Ecology 40 (1):15-27. http://dx.doi.org/10.1007/s10745-011-9448-1

Ribot, J. 2011. Vulnerability before adaptation: toward transformative climate action: from affirmative to transformative climate action Global Environmental Change 21(4):1160-1162. http://dx.doi.org/10.1016/j.gloenvcha.2011.07.008

Riedlinger, D., and F. Berkes. 2001. Contributions of traditional knowledge to understanding climate change in the Canadian Arctic. Polar Record 37:315-328. http://dx.doi.org/10.1017/ $\underline{\text { S0032247400017058 }}$ 
Robbins, P. 2012. Political ecology: a critical introduction. Wiley Blackwell, London, UK. http://dx.doi.org/10.4135/9781412953924. $\underline{\mathrm{n} 850}$

Roediger, H. L., III. 1996. Memory illusions. Journal of Memory and Language 35:76-100.

Roncoli, C. 2006. Ethnographic and participatory approaches to research on farmers' responses to climate predictions. Climate Research 33(1):81. http://dx.doi.org/10.3354/cr033081

Roturiera, S., and M. Roué. 2009. Of forest, snow and lichen: Sámi reindeer herders' knowledge of winter pastures in northern Sweden. Forest Ecology and Management 258:1960-1967. http:// dx.doi.org/10.1016/j.foreco.2009.07.045

Ruddiman, W. F. 2013. The Anthropocene. Annual Review of Earth and Planetary Sciences 41:45-68. http://dx.doi.org/10.1146/ annurev-earth-050212-123944

Rudiak-Gould, P. 2012. Promiscuous corroboration and climate change translation: a case study from the Marshall Islands. Global Environmental Change 22:46-54. http://dx.doi.org/10.1016/j. gloenvcha.2011.09.011

Rudiak-Gould, P. 2013. "We have seen it with our own eyes": Why we disagree about climate change visibility. Weather, Climate and Society 5:120-132. http://dx.doi.org/10.1175/wcas-d-12-00034.1

Rudiak-Gould, P. 2014. The influence of science communication on indigenous climate change perception: theoretical and practical implications. Human Ecology 42:75-86. http://dx.doi. org/10.1007/s10745-013-9605-9

Ruiz-Mallén, I., and E. Corbera. 2013. Community-based conservation and traditional ecological knowledge: implications for social-ecological resilience. Ecology and Society 18(4):12. http://dx.doi.org/10.5751/es-05867-180412

Sánchez-Cortés, M. S., and E. L. Chavero. 2011. Indigenous perception of changes in climate variability and its relationship with agriculture in a Zoque community of Chiapas, Mexico. Climatic Change 107:363-389. http://dx.doi.org/10.1007/ s10584-010-9972-9

Schneider, S. H., and T. L. Root. 1996. Ecological implications of climate change will include surprises. Biodiversity \& Conservation 5:1109-1119. http://dx.doi.org/10.1007/BF00052720

Simons, D. J., and R. A. Rensink. 2005. Change blindness: past, present and future. Trends in Cognitive Sciences 9:16-20. http:// dx.doi.org/10.1016/j.tics.2004.11.006

Spence, A., W. Poortinga, C. Butler, and N. F. Pidgeon. 2011. Perceptions of climate change and willingness to save energy related to flood experience. Nature Climate Change 1:46-49. http://dx.doi.org/10.1038/nclimate1059

Speranza, C. I., B. Kiteme, P. Ambenje, U. Wiesmann, and S. Makali. 2010. Indigenous knowledge related to climate variability and change: insights from droughts in semi-arid areas of former Makueni District, Kenya. Climatic Change 100:295-315. http:// dx.doi.org/10.1007/s10584-009-9713-0

Stamm, K. R., F. Clark, and P. R. Eblacas. 2000. Mass communication and public understanding of environmental problems: the case of global warming. Public Understanding of Science 9(3):219-237. http://dx.doi.org/10.1088/0963-6625/9/3/302
Steffen, W., A. Persson, L. Deutsch, J. Zalasiewicz, M. Williams, K. Richardson, C. Crumley, P. Crutzen, C. Folke, L. Gordon, M. Molina, V. Ramanathan, J. RockstrÃ $\mid \mathrm{m}$, M. Scheffer, H. J. Schellnhuber, and U. Svedin. 2011. The Anthropocene: from global change to planetary stewardship. Ambio 40(7):739-761. http://dx.doi.org/10.1007/s13280-011-0185-X

Steffen, W., A. Sanderson, J. Jäger, P. D. Tyson, B. Moore, III, P. A. Matson, K. Richardson, F. Oldfield, H. -J. Schellnhuber, B. L. Turner, II, and R. J. Wasson. 2004. Global change and the earth system: a planet under pressure. Springer, Heidelberg, Germany.

Stern, P. C. 2000. New environmental theories: toward a coherent theory of environmentally significant behavior. Journal of Social Issues 56:407-424. http://dx.doi.org/10.1111/0022-4537.00175

Swim, J. S., T. Clayton, R. Doherty, G. Gifford, J. R. Howard, P. Stern, and E. U. Weber. 2009. Psychology and global climate change: addressing a multifaceted phenomenon and set of challenges. APA Task Force on the Interface between Psychology and Global Climate Change, Pennsylvania, USA.

Tàbara, J. D., X. Dai, G. Jia, D. McEvoy, H. Neufeldt, A. Serra, S. Werners, and J. J. West. 2010. The climate learning ladder. A pragmatic procedure to support climate adaptation. Environmental Policy and Governance 20(1):1-11. http://dx.doi.org/10.1002/ eet. 530

Thornton, T. F., and N. Manasfi. 2010. Adaptation-genuine and spurious: demystifying adaptation processes in relation to climate change. Environment and Society: Advances in Research 1(9):132155. http://dx.doi.org/10.3167/ares.2010.010107

Tuhiwai Smith, L. 1999. Decolonizing methodologies: research and indigenous peoples. Zed Books, New York, New York, USA.

Turner, B. L., II, R. E. Kasperson, W. B. Meyer, K. M. Dow, D. Golding, J. X. Kasperson, R. C. Mitchell, and S. J. Ratick. 1990. Two types of global environmental change: definitional and spatial scale issues in their human dimensions. Global Environmental Change 1:14-22. http://dx.doi.org/10.1016/0959-3780 (90)90004-S

Turner, N. J., R. Gregory, C. Brooks, L. Failing, and T. Satterfield. 2008. From invisibility to transparency: identifying the implications. Ecology and Society 13(2):7.

Turnhout, E., B. Bloomfield, M. Hulme, J. Vogel, and B. Wynne. 2012. Conservation policy: listen to the voices of experience. Nature 488:454-455. http://dx.doi.org/10.1038/488454a

Tyler, N. J. C., J. M. Turi, M. A. Sundset, K. Strøm Bull, M. N. Sara, E. Reinert, N. Oskal, C. Nellemann, J. J. McCarthy, S. D. Mathiesen, M. L. Martello, O. H. Magga, G. K. Hovelsrud, I. Hanssen-Bauer, N. I. Eira, I. M. G. Eira, and R. W. Corell. 2007. Saami reindeer pastoralism under climate change: applying a generalized framework for vulnerability studies to a sub-arctic social-ecological system. Global Environmental Change 17:191206. http://dx.doi.org/10.1016/j.gloenvcha.2006.06.001

Veland, S., R. Howitt, D. Dominey-Howes, F. Thomalla, and D. Houston. 2013. Procedural vulnerability: understanding environmental change in a remote indigenous community. Global Environmental Change 23:314-326. http://dx.doi.org/10.1016/j. gloenvcha.2012.10.009 
Victor, D. G. 2015. Climate change: embed the social sciences in climate policy. Nature 520(7545):27-29. http://dx.doi.org/10.1038/520027a

Vignola, R., R. Koellner, R. W. Scholz, and T. L. McDaniels. 2010. Decision-making by farmers regarding ecosystem services: factors affecting soil conservation efforts in Costa Rica. Land Use Policy 27:1132-1142. http://dx.doi.org/10.1016/j.landusepol.2010.03.003

Vitousek, P. M. 1994. Beyond global warming: ecology and global change. Ecology 75(7):1861-1876. http://dx.doi.org/10.2307/1941591

von Glasenapp, M., and T. F. Thornton. 2011. Traditional ecological knowledge of Swiss alpine farmers and their resilience to socioecological change. Human Ecology 39(6):769-781. http:// dx.doi.org/10.1007/s10745-011-9427-6

Voyer, M., W. Gladstone, and H. Goodall. 2012. Methods of social assessment in Marine Protected Area planning: Is public participation enough? Marine Policy 36:432-439. http://dx.doi. org/10.1016/j.marpol.2011.08.002

Weatherhead, E., S. Gearheard, and R. G. Barry. 2010. Changes in weather persistence: insight from Inuit knowledge. Global Environmental Change 20:523-528. http://dx.doi.org/10.1016/j. gloenvcha.2010.02.002

Weber, E. U. 2013. Psychology: seeing is believing. Nature Climate Change 3:312-313. http://dx.doi.org/10.1038/nclimate1859

Weber, E. U., and E. J. Johnson. 2009. Mindful judgment and decision making. Annual Review of Psychology 60:53-85. http:// dx.doi.org/10.1146/annurev.psych.60.110707.163633

West, C. T., C. Roncoli, and F. Ouattara. 2008. Local perceptions and regional climate trends on the central plateau of Burkina Faso. Land Degradation \& Development 19:289-304. http://dx. doi.org/10.1002/ldr.842

Wiens, J. A., and D. Bachelet. 2010. Matching the multiple scales of conservation with the multiple scales of climate change. Conservation Biology 24(1):51-62. http://dx.doi.org/10.1111/ j.1523-1739.2009.01409.x

Wilbanks, T. J., and R. W. Kates. 1999. Global change in local places: how scale matters. Climatic Change 43:601-628. http://dx. doi.org/10.1023/A:1005418924748

Yeh, E. T. 2015. 'How can experience of local residents be "knowledge"?' Challenges in interdisciplinary climate change research. Area 48(1):34-40. http://dx.doi.org/10.1111/area.12189

Yu, Q., W. Wu, Z. Liu, P. H. Verburg, T. Xia, P. Yang, Z. Lu, L. You, and H. Tang. 2014. Interpretation of climate change and agricultural adaptations by local household farmers: a case study at Bin County, northeast China. Journal of Integrative Agriculture 13(7):1599-1608. http://dx.doi.org/10.1016/s2095-3119(14)60805-4

Zalasiewicz, J., A. Smith, M. Hounslow, M. Williams, A. Gale, J. Powell, C. Waters, T. L. Barry, P. R. Bown, P. Brenchley, D. Cantrill, P. Gibbard, F. J. Gregory, R. Knox, J. Marshall, M. Oates, P. Rawson, P. Stone, and N. Trewin. 2008. Are we now living in the Anthropocene? GSA Today 18:4-8. http://dx.doi. org/10.1130/GSAT01802A.1
Zalasiewicz, J., M. Williams, A. Haywood, and M. Ellis. 2011. The Anthropocene: a new epoch of geological time? Philosophical Transactions of the Royal Society A 369:835-841. http://dx.doi. org/10.1098/rsta.2010.0339

Zaval, L., E. A. Keenan, E. J. Johnson, and E. U. Weber. 2014. How warm days increase belief in global warming. Nature Climate Change 4:143-147.0 http://dx.doi.org/10.1038/nclimate2093 


\section{Appendix 1: Database Matrix}

In reviewing each article, we inserted the data for each variable listed below into the readyformulated Excel database. Where information was not provided or not clear, the data cells were left blank. Answers were mostly quantitative, pre-coded and categorized (as shown in Table A1 and A2 below) to ease subsequent data analysis. Similarly, as seen in Table 3, we used predefined categories (Mobility, Exchange, Rationing, Pooling, Diversification, Intensification, Innovation, Revitalization, and Other) to analyze adaptation type. We used basic statistics in Excel to analyze our results. Throughout, we critically examined data collection procedures and analytical methods used to support the information provided in the studies.

\section{Part I:}

Table A1. Descriptive characteristics

\begin{tabular}{|c|c|c|c|}
\hline Variable & Description & Format & Categories \\
\hline Num & $\begin{array}{l}\text { Number of article (assigned } \\
\text { by us: from } 1 \text { onwards) }\end{array}$ & Number & --- \\
\hline Ref & $\begin{array}{l}\text { Full scientific reference, eg: } \\
\text { Author et al. (Year) Title, } \\
\text { Journal, vol: (issue), pgs. }\end{array}$ & Text & --- \\
\hline Year & Year that article published & Number & --- \\
\hline Jour & Journal title & Text & --- \\
\hline Auth & $\begin{array}{l}\text { Lead author affiliation } \\
\text { country }\end{array}$ & Text & \\
\hline Group & Group studied & Text & Coded later into the following: \\
\hline Data year & $\begin{array}{l}\text { Year(s) that data were } \\
\text { collected }\end{array}$ & Number & \\
\hline Cont & $\begin{array}{l}\text { Continent (classification of } \\
\text { Encyclopedia Britannica 2006) }\end{array}$ & Number & $\begin{array}{l}1=\text { Africa } \\
2=\text { Europe } \\
3=\text { Asia } \\
4=\text { North America (including Central } \\
\text { America) } \\
5=\text { South America } \\
6=\text { Australia } \\
7=\text { Antarctica }\end{array}$ \\
\hline Region & Region & Number & $\begin{array}{l}101=\text { Northern Africa }(\text { Maghreb) } \\
102=\text { Sahel } \\
103=\text { Rest of Western Africa } 104=\text { East Africa } \\
\text { (excluding the Horn of Africa) } \\
105=\text { Central Africa } \\
106=\text { Southern Africa } \\
107=\text { Horn of Africa (Eritrea, Djibouti, } \\
\text { Ethiopia and Somalia) } \\
107=\text { African islands } \\
--- \\
201=\text { Eastern Europe } \\
202=\text { Western Europe (excluding Nordic } \\
\text { countries) } \\
--- \\
301=\text { Western Asia and Middle East } \\
302=\text { South-East Asia (Pacific) } \\
303=\text { South-Central Asia (including India and } \\
\text { the Himalayas) } \\
304=\text { Eastern Asia (including Mongolia and } \\
\text { Taiwan) } \\
305=\text { North Asia (Russia, excluding Siberia) } \\
--- \\
401=\text { United States and Canada (excluding } \\
\text { Arctic regions) } \\
402=\text { Mexico } \\
403=\text { Rest of Central America }\end{array}$ \\
\hline
\end{tabular}




\begin{tabular}{|c|c|c|c|}
\hline & & & $\begin{array}{l}404=\text { Caribbean Islands } \\
501=\text { Andean region (including Altiplano) } \\
502=\text { Amazon Basin } \\
503=\text { Atlantic littoral } \\
504=\text { Cerrado and Pampa } \\
505=\text { The Guyana } \\
506=\text { Southern South America (mainly } \\
\text { Patagonia and Tierra de Fuego) } \\
--- \\
601=\text { Australia } \\
602=\text { New Zealand } \\
603=\text { South }- \text { Pacific islands } \\
801=\text { Arctic (including Alaska, Siberia and } \\
\text { Lapland) }\end{array}$ \\
\hline Country & Country/ies of study & Text & --- \\
\hline Climate & $\begin{array}{l}\text { Type of climate (Köppen } \\
\text { climate classification) }\end{array}$ & Number & $\begin{array}{l}10=\text { tropical } / \text { megathermal } \\
20=\text { dry }(\text { arid and semiarid }) \\
30=\text { temperate } / \text { mesothermal } \\
40=\text { continental } / \text { microthermal } \\
50=\text { polar and alpine }\end{array}$ \\
\hline Livelihood_1 & $\begin{array}{l}\text { Main livelihood strategy / } \\
\text { subsistence activity }\end{array}$ & Number & $\begin{array}{l}1=\text { hunter-gatherer } 2=\text { small-scale } \\
\text { agriculture } 3=\text { intensive } \\
\text { agriculture } 4=\text { fishing } 5=\text { NTFP } \\
\text { collection } 6=\text { Pastoralism/animal } \\
\text { husbandry } 7=\text { wage labour } 8=\text { other }\end{array}$ \\
\hline Livelihood_2 & $\begin{array}{l}\text { Secondary livelihood strategy } \\
\text { / subsistence activity }\end{array}$ & Number & $\begin{array}{l}1=\text { hunter-gatherer } 2=\text { small-scale } \\
\text { agriculture } 3=\text { intensive } \\
\text { agriculture } 4=\text { fishing } 5=\text { NTFP } \\
\text { collection } 6=\text { Pastoralism/animal } \\
\text { husbandry } 7=\text { wage labour } 8=\text { other }\end{array}$ \\
\hline Livelihood_3 & $\begin{array}{l}\text { Tertiary livelihood strategy / } \\
\text { subsistence activity }\end{array}$ & Number & $\begin{array}{l}1=\text { hunter-gatherer } 2=\text { small-scale } \\
\text { agriculture } 3=\text { intensive } \\
\text { agriculture } 4=\text { fishing } 5=\text { NTFP } \\
\text { collection } 6=\text { Pastoralism/animal } \\
\text { husbandry } 7=\text { wage labour } 8=\text { other }\end{array}$ \\
\hline Sample & $\begin{array}{l}\text { Sample size studied (number } \\
\text { of individuals } \\
\text { studied/interviewed/surveyed) }\end{array}$ & Number & --- \\
\hline Method & Method for data collection & Number & $\begin{array}{l}1=\text { quantitative } \\
2=\text { qualitative } \\
3=\text { both quantitative and } \\
\text { qualitative }\end{array}$ \\
\hline Goal_perc & $\begin{array}{l}\text { Local perceptions of change } \\
\text { as goal of article }\end{array}$ & Number & $\begin{array}{l}\text { Was the primary goal of the article } \\
\text { to collect local perceptions of } \\
\text { change? } \\
1=\text { Main goal } \\
2=\text { one among several goals } \\
3=\text { not a goal, perceptions appear } \\
\text { only in a tangent way }\end{array}$ \\
\hline Goal_chang & $\begin{array}{l}\text { Documenting change as goal } \\
\text { of article }\end{array}$ & Number & $\begin{array}{l}\text { Was one of the goals of the article } \\
\text { to collect actual documentation of } \\
\text { change? } \\
1 \text { = Main goal } \\
2=\text { one among several goals } \\
3=\text { not a goal, documentation }\end{array}$ \\
\hline
\end{tabular}




\begin{tabular}{|c|c|c|c|}
\hline & & & appears only in a tangent way \\
\hline Goal_sci & $\begin{array}{l}\text { Comparing scientific data } \\
\text { with local perceptions as goal } \\
\text { of article }\end{array}$ & Number & $\begin{array}{l}\text { Was one of the goals of the article } \\
\text { to compare local perceptions with } \\
\text { scientific evidence? } \\
1=\text { Main goal } \\
2=\text { one among several goals } \\
3=\text { not a goal, comparison } \\
\text { appears only in a tangent way }\end{array}$ \\
\hline Notes & $\begin{array}{l}\text { Notes (be as brief and to the } \\
\text { point as possible)! }\end{array}$ & Text & --- \\
\hline
\end{tabular}

Note: For all the above, code "-9" for "Not mentioned/not clear"

\section{Table A2. Perceptions and understandings of Global Environmental Change}

This Table is intended to compile all the information on the perceptions, understandings and manifestations of Global Environmental Change in the publications referred to in Table 2. If some information is missing, not available, or not mentioned, code as " -9 ".

\begin{tabular}{|c|c|c|c|}
\hline Variable & Description & Format & Categories \\
\hline Num & Number & Number & --- \\
\hline $\begin{array}{l}\text { Type_chang_1 } \\
\text { Type_chang_2 } \\
\text { Type_chang_3 } \\
\text { Type_chang_4 } \\
\text { Type_chang_5 } \\
\text { Type_chang_6 } \\
\text { Type_chang_7 }\end{array}$ & $\begin{array}{l}\text { Type of perceived } \\
\text { contemporary change }\end{array}$ & Number & $\begin{array}{l}1=\text { temperature change } \\
2=\text { rainfall change } \\
3=\text { drought } \\
4=\text { erosion } \\
5=\text { floods } \\
6=\text { sea level rise } \\
7=\text { deforestation } \\
8=\text { biodiversity change } \\
9=\text { invasive species } \\
10=\text { permafrost/ice/glaciers } \\
11=\text { fire } \\
12=\text { winds (excl. tornadoes/cyclones) } \\
13=\text { storms } \\
14=\text { extreme events (incl. } \\
\text { tornadoes/cyclones/tsunamis/earthquakes) } \\
15=\text { phenology/seasonality } \\
16=\text { other (name what) }\end{array}$ \\
\hline Length & Decade & Number & $\begin{array}{l}\text { Decade since change is } \\
\text { recorded/perceived (e.g. 1980s) }\end{array}$ \\
\hline Spat_imp & Spatial impact & Number & $\begin{array}{l}\text { Is the change perceived to be only } \\
\text { local, or also regional, or even global? } \\
1=\text { local } \\
2=\text { regional } \\
3=\text { global } \\
4=\text { locally not perceived as change }\end{array}$ \\
\hline Spat_driver & Spatial driver of change & Number & $\begin{array}{l}\text { Is the perceived main driver of change } \\
\text { perceived to be local, regional, or } \\
\text { global? } \\
1=\text { local } \\
2=\text { regional } \\
3=\text { global } \\
4=\text { locally not perceived as change }\end{array}$ \\
\hline Driver & $\begin{array}{l}\text { Perceived driver of } \\
\text { change }\end{array}$ & Number & $\begin{array}{l}\text { Perceived driver of change? } \\
1=\text { human-induced; } \\
2=\text { natural phenomena; } \\
3=\text { supernatural/religious/cosmological }\end{array}$ \\
\hline
\end{tabular}




\begin{tabular}{|c|c|c|c|}
\hline & & & $4=$ other \\
\hline Change_eval & $\begin{array}{l}\text { Change perceived as } \\
\text { positive or negative }\end{array}$ & Number & $\begin{array}{l}\text { Change perceived as positive or } \\
\text { negative? } \\
1=\text { Positive } \\
0=\text { Negative } \\
2=\text { Both positive and negative }\end{array}$ \\
\hline Change_inv & Invisibility of change & Number & $\begin{array}{l}\text { Is the change perceived by the naked } \\
\text { eye }(=1) \text { ? Has it been recorded only } \\
\text { through the use of technological } \\
\text { equipment/measurement }(=0) \text { ? Or } \\
\text { both }(=2) \text { ? }\end{array}$ \\
\hline Imp_liv & $\begin{array}{l}\text { Explicitly stated direct } \\
\text { impact on livelihood }\end{array}$ & Number & $\begin{array}{l}\text { Are there direct impacts of the change } \\
\text { on local livelihoods? } \\
\text { Yes }=1 \\
\text { No }=0\end{array}$ \\
\hline Imp_cult & $\begin{array}{l}\text { Explicitly stated direct } \\
\text { impact on culture/social } \\
\text { norms }\end{array}$ & Number & $\begin{array}{l}\text { Are there direct impacts of the change } \\
\text { on culture/social norms? } \\
\text { Yes }=1 \\
\text { No=0 }\end{array}$ \\
\hline Imp_envir & $\begin{array}{l}\text { Explicitly stated direct } \\
\text { impact on the } \\
\text { environment }\end{array}$ & Number & $\begin{array}{l}\text { Are there direct impacts of the change } \\
\text { on the environment? } \\
\text { Yes }=1 \\
\text { No }=0\end{array}$ \\
\hline Local_conc & $\begin{array}{l}\text { Local epistemology, } \\
\text { ontology, cosmology, } \\
\text { cultural meaning, } \\
\text { conceptuatlisation, etc }\end{array}$ & Number & $\begin{array}{l}\text { Do the authors take into account local } \\
\text { conceptions of the environment in } \\
\text { their study? (i.e. do they rely -even } \\
\text { partly- on local ethnological } \\
\text { explanations?) } \\
\text { Yes }=1 \\
\text { No=0 }\end{array}$ \\
\hline Local_psy & $\begin{array}{l}\text { Local psychology and } \\
\text { processes that shape } \\
\text { perceptions of change }\end{array}$ & Number & $\begin{array}{l}\text { Do the authors take into account } \\
\text { psychological dimensions of the } \\
\text { environmental perceptions? (e.g. } \\
\text { shifting baselines, change blindness, } \\
\text { amnesia, media effects, etc.) } \\
\text { Yes }=1 \\
\text { No }=0\end{array}$ \\
\hline Conc_sci & $\begin{array}{l}\text { Report/perceptions } \\
\text { concordant or not with } \\
\text { scientific data/info? }\end{array}$ & Number & $\begin{array}{l}1=\text { Yes, local=scientific reports } \\
0=\text { No, local differs from scientific } \\
2=\text { Both yes and no } \\
-9=\text { not reported }\end{array}$ \\
\hline Own_sci & $\begin{array}{l}\text { Self-measured scientific } \\
\text { data }\end{array}$ & Number & $\begin{array}{l}\text { Does the article contain primary } \\
\text { scientific data, measurements, records on } \\
\text { the change apart from local perceptions? } \\
1=\text { Yes } \\
0=\text { No }\end{array}$ \\
\hline Loc_resp & $\begin{array}{l}\text { Local response to } \\
\text { change }\end{array}$ & Number & $\begin{array}{l}\text { Does the article mention any local } \\
\text { responses to change? } \\
1=\text { Yes } \\
0=\mathrm{No}\end{array}$ \\
\hline Loc_adapt & $\begin{array}{l}\text { Local adaptation to } \\
\text { change }\end{array}$ & Number & $\begin{array}{l}\text { If there are responses/adaptation } \\
\text { measures to change, are these: } \\
1=\text { based on local knowledge } \\
2=\text { based on modern technology } \\
3=\text { both }\end{array}$ \\
\hline
\end{tabular}




\begin{tabular}{|l|l|l|l|}
\hline Loc_init & $\begin{array}{l}\text { Externally or locally } \\
\text { driven adaptation } \\
\text { strategies }\end{array}$ & Number & $\begin{array}{l}\text { If there are responses/adaptation } \\
\text { measures to change, are these: } \\
1=\text { only locally driven } \\
\text { 2= externally driven (ex. NGOs, } \\
\end{array}$ \\
& & & $\begin{array}{l}\text { development aid, scientists, } \\
\text { government) } \\
3=\text { both }\end{array}$ \\
& & & --- \\
\hline Notes & Notes & Text & \\
\hline
\end{tabular}


Appendix 2. Articles reviewed $(n=126)$

\begin{tabular}{|c|c|}
\hline$\#$ & Reference \\
\hline 1 & $\begin{array}{l}\text { Chaudhary, P.; Bawa, K. S. (2011). Local perceptions of climate change validated by scientific } \\
\text { evidence in the Himalayas. Biology Letters (2011) 1-4. }\end{array}$ \\
\hline 2 & $\begin{array}{l}\text { Gioli, G.; Khan, T.; Scheffran, J. (2014). Climatic and environmental change in the Karakoram: } \\
\text { making sense of community perceptions and adaptation strategies. Reg Environ Change 14:1151- } \\
1162\end{array}$ \\
\hline 3 & $\begin{array}{l}\text { Byg, A.; Salick, J.(2009). Local perspectives on a global phenomenon - Climate change in Eastern } \\
\text { Tibetan villages. Global Environmental Change } 2009 \text { 19: 156-166. }\end{array}$ \\
\hline 4 & $\begin{array}{l}\text { Joshi, S.; Jasra, W.A.; Ismail, M.; Shrestha, R. M.; Yi, S. L.; Wu, N. (2013). Herders' Perceptions of } \\
\text { and Responses to Climate Change in Northern Pakistan. Environmental Management 52:639-648. }\end{array}$ \\
\hline 5 & $\begin{array}{l}\text { Rai, J. K. (2010). Global and Local Discourses on Climate Change: A Perspective from the Concept of } \\
\text { Embeddedness. Dhaulagiri Journal of Sociology and Anthropology 4:143-180. }\end{array}$ \\
\hline 7 & $\begin{array}{l}\text { Vedwan, N. (2006). Culture, Climate and the Environment: Local Knowledge and Perception of } \\
\text { Climate Change among Apple Growers in Northwestern India. Journal of Ecological Anthropology } \\
\text { 10: 4-18. }\end{array}$ \\
\hline 8 & $\begin{array}{l}\text { Vedwan, N.; Rhoades, R. E. (2001). Climate change in the Western Himalayas of India: a study of } \\
\text { local perception and response. Climate Research 2001, 19: 109-117. }\end{array}$ \\
\hline 9 & $\begin{array}{l}\text { Berman, M.; Kofinas, G. (2004). Hunting for models: grounded and rational choice approaches } \\
\text { to analyzing climate effects on subsistence hunting in an Arctic community. Ecological Economics } \\
\text { 49:31-46 }\end{array}$ \\
\hline 10 & $\begin{array}{l}\text { Cochran, P.; Huntington, O. H.; Pungowiyi, C.; Tom, S.; Chapin III, F. S.; Huntington, H. P.; Maynard, } \\
\text { N. G.; Trainor, S.F. (2013). Indigenous frameworks for observing and responding to climate change } \\
\text { in Alaska. Climatic Change. }\end{array}$ \\
\hline 11 & $\begin{array}{l}\text { Cruikshank, J. (2001). Glaciers and Climate Change: Perspectives from Oral Tradition. Arctic vol. 54, } \\
4 \text { (2001): } 377 \text { - } 393 .\end{array}$ \\
\hline 12 & $\begin{array}{l}\text { Duerden, F. (2004). Translating Climate Change Impacts at the Community Level. Arctic vol. 57(2): } \\
204-212 .\end{array}$ \\
\hline 13 & $\begin{array}{l}\text { McNeeley, S. M.; Shulski, M. D. (2011). Anatomy of a closing window: Vulnerability to changing } \\
\text { seasonality in Interior Alaska. Global Environmental Change 21:464-473. }\end{array}$ \\
\hline 14 & $\begin{array}{l}\text { Pearce, T. D.; Ford, J. D.; Laidler, G. J.; Smit, B.; Duerden, F.; Allarut, M.; Andrachuk, M.; Baryluk, S.; } \\
\text { Dialla, A.; Elee, P.; Goose, A.; Ikummaq, T.; Joamie, E.; Kataoyak, F.; Loring, E.; Meakin, S.; Nickels, } \\
\text { S.; Shappa, K.; Shirley, J.; Wandel, J. (2009). Community collaboration and climate change research } \\
\text { in the Canadian Arctic. Polar Research 28:10-27. }\end{array}$ \\
\hline 15 & $\begin{array}{l}\text { Ford, J. D.; Smit, B.; Wandel, J. (2006). Vulnerability to climate change in the Arctic: A case study } \\
\text { from Arctic Bay, Canada. Global Environmental Change (2006) 16:145-160 }\end{array}$ \\
\hline 16 & $\begin{array}{l}\text { Ford, J. D.; Smit, B.; Wandel, J.; MacDonald, J. (2006). Vulnerability to climate change in Igloolik, } \\
\text { Nunavut: what we can learn from the past and present. Polar Record } 42 \text { (221): 127-138. }\end{array}$ \\
\hline 17 & $\begin{array}{l}\text { Ford, J.; Pearce, T.; Smit, B.; Wandel, J.; Allurut, M.; Shappa, K.; Ittusujurat, H.; Qrunnut, K. (2007). } \\
\text { Reducing Vulnerability to Climate Change in the Arctic: The Case of Nunavut, Canada. Arctic } \\
\text { Vol. 60(2):150-166. }\end{array}$ \\
\hline 18 & $\begin{array}{l}\text { Ford, J. D.; Smit, B.; Wandel, J.; Allurut, M.; Shappa, K.; Ittusarjuat, H.; Qrunnut, K. (2008). Climate } \\
\text { change in the Arctic: current and future vulnerability in two Inuit communities in Canada. The } \\
\text { Geographical Journal } 174 \text { (2008) 1: 45-62. }\end{array}$ \\
\hline 19 & $\begin{array}{l}\text { Ford, J. D. (2009). Dangerous climate change and the importance of adaptation for the Arctic's } \\
\text { Inuit population. Environmental Research Letters } 4\end{array}$ \\
\hline 20 & $\begin{array}{l}\text { Gearheard, S.; Matumeak, W.; Angutikjuaq, I.; Maslanik, J.; Huntington, H. P.; Leavitt, J.; Kagak, D. } \\
\text { M.; Tigullaraq, G.; Barry R. G. (2006). "It's Not that Simple": A Collaborative Comparison of Sea Ice } \\
\text { Environments, Their Uses, Observed Changes, and Adaptations in Barrow, Alaska, USA, and Clyde }\end{array}$ \\
\hline
\end{tabular}




\begin{tabular}{|c|c|}
\hline & River, Nunavut, Canada. Ambio Vol. 35 (2006) 4:204-212. \\
\hline 21 & $\begin{array}{l}\text { Gearheard, S.; Pocernich, M.; Stewart, R.; Sanguya, J.; Huntington, H. P. (2010). Linking Inuit } \\
\text { knowledge and meteorological station observations to understand changing wind patterns at Clyde } \\
\text { River, Nunavut. Climatic Change } 100 \text { (2): 267-294, }\end{array}$ \\
\hline 22 & $\begin{array}{l}\text { Laidler, G. J. (2006) Inuit and scientific perspectives on the relationship between sea ice and climate } \\
\text { change: the ideal complement? Climatic Change (2006) 78:407-444. }\end{array}$ \\
\hline 23 & $\begin{array}{l}\text { Leduc, T. B. (2006). Inuit economic adaptations for a changing global climate. Ecological Economics } \\
\text { (2006) 60:27-35. }\end{array}$ \\
\hline 24 & $\begin{array}{l}\text { Weatherhead, E.; Gearheard, S.; Barry, R.G. (2010). Changes in weather persistence: Insight from } \\
\text { Inuit knowledge. Global Environmental Change (2010) 20:523-528. }\end{array}$ \\
\hline 25 & $\begin{array}{l}\text { Alessa, L.; Kliskey, A.; Williams, P.; Barton, M. (2008). Perception of change in freshwater in remote } \\
\text { resource-dependent Arctic communities. Global Environmental Change 2008) } 18: 153-164 .\end{array}$ \\
\hline 26 & $\begin{array}{l}\text { Eisner, W. R.; Cuomo, C. J.; Hinkel, K. M.; Jones, B. M.; Brower, R. H. (2009). Advancing Landscape } \\
\text { Change Research through the Incorporation of Iñupiaq Knowledge. Arctic vol. } 62 \text { (2009) 4: } 429- \\
442 .\end{array}$ \\
\hline 27 & $\begin{array}{l}\text { Roturiera, S.; Roue', M. (2009). Of forest, snow and lichen: Sami reindeer herders' knowledge of } \\
\text { winter pastures in northern Sweden. Forest Ecology and Management (2009) 258:1960-1967. }\end{array}$ \\
\hline 28 & $\begin{array}{l}\text { Tyler, N. J. C.; Turi, J. M.; Sundset, M. A.; Strøm Bull, K.; Sara, M. N.; Reinert, E.; Oskal, N.; } \\
\text { Nellemann, C.; McCarthy, J. J.; Mathiesen, S. D.; Martello, M. L.; Magga, O. H.; Hovelsrud, G. K.; } \\
\text { Hanssen-Bauer, I.; Eira, N.I.; Eira, I. M. G.; Corell, R. W. (2007). Saami reindeer pastoralism under } \\
\text { climate change: Applying a generalized framework for vulnerability studies to a sub-arctic social- } \\
\text { ecological system. Global Environmental Change (2007) 17:191-206. }\end{array}$ \\
\hline 29 & $\begin{array}{l}\text { Forbes, B. C.; Stammler, F.; Kumpula, T.; Meschtyb, N.; Pajunen, A.; Kaarlejärvi, E. (2009). High } \\
\text { resilience in the Yamal-Nenets social- ecological system, West Siberian Arctic, Russia. Proceedings } \\
\text { of the National Academy of Sciences. 12/2009; 106(52):22041-8. }\end{array}$ \\
\hline 30 & $\begin{array}{l}\text { Kumpula, T.; Forbes, B. C.; Stammler, F. (2010). Remote Sensing and Local Knowledge of } \\
\text { Hydrocarbon Exploitation: The Case of Bovanenkovo, Yamal Peninsula, West Siberia, Russia. Arctic } \\
\text { Vol. } 63 \text { (2010) 2:165 - 178. }\end{array}$ \\
\hline 31 & $\begin{array}{l}\text { Kumpula, T.; Forbes, B. C.; Stammler, F.; Meschtyb, N. (2012). Dynamics of a Coupled System: } \\
\text { Multi-Resolution Remote Sensing in Assessing Social-Ecological Responses during } \\
25 \text { Years of Gas Field Development in Arctic Russia. Remote Sensing (2012) 4:1046-1068. }\end{array}$ \\
\hline 32 & $\begin{array}{l}\text { Boissière, M.; Locatelli, B.; Sheil, D.; Padmanaba, M.; Sadjudin, E. (2013). Local perceptions of } \\
\text { climate variability and change in tropical forests of Papua, Indonesia. Ecology and Society } 18 \text { (4): } \\
\text { 13. }\end{array}$ \\
\hline 33 & $\begin{array}{l}\text { Combest-Friedman, C.; Christie, P.; Miles, E. (2012). Household perceptions of coastal hazards and } \\
\text { climate change in the Central Philippines. Journal of Environmental Management (2012) 112:137- } \\
148 .\end{array}$ \\
\hline 34 & $\begin{array}{l}\text { Su, G. S.; Macawile, J.; Villarino, A.; Agapito, J.; Gomez, N. (2011). Recognizing Local People's } \\
\text { Perceptions Towards Deforestation in Quezon Province, Philippines. Environmental Research } \\
\text { Journal (2011) 5:131-135. }\end{array}$ \\
\hline 35 & $\begin{array}{l}\text { Buys, L.; Miller, E.; Van Megen, K. (2012) Conceptualising climate change in rural Australia: } \\
\text { community perceptions, attitudes and (in)actions. Regional Environmental Change (2012) 1:237- } \\
248 .\end{array}$ \\
\hline 36 & $\begin{array}{l}\text { Green, D.; Billy, J.; Tapim, A. (2010). Indigenous Australians' knowledge of weather } \\
\text { and climate. Climatic Change (2010) 100:337-354. }\end{array}$ \\
\hline 37 & $\begin{array}{l}\text { Petheram, L.; Zander, K. K.; Campbell, B. M.; High, C. and Stacey, N. (2010). 'Strange changes': } \\
\text { indigenous perspectives of climate change and adaptation in NE Arnhem Land (Australia). Global } \\
\text { Environmental Change } 20 \text { (2010) 4:681-692. }\end{array}$ \\
\hline 38 & $\begin{array}{l}\text { Waudby, H. P.; Petit, S.; Robinson, G. (2012). Pastoralists' perceptions of biodiversity and land } \\
\text { management strategies in thear id Stony Plains region of South Australia: Implications for policy }\end{array}$ \\
\hline
\end{tabular}




\begin{tabular}{|c|c|}
\hline & makers. Journal of Environmental Management (2012) 112:96-103. \\
\hline 39 & $\begin{array}{l}\text { Bridges, K.W.; McClatchey, W. C. (2009). Living on the margin: Ethnoecological insights from } \\
\text { Marshall Islanders at Rongelap atoll. Global Environmental Change (2009) 19:140-146. }\end{array}$ \\
\hline 40 & $\begin{array}{l}\text { Lauer, M.; Aswani, S. (2010). Indigenous Knowledge and Long-term Ecological Change: Detection, } \\
\text { Interpretation, and Responses to Changing Ecological Conditions in Pacific Island Communities. } \\
\text { Environmental Management (2010) 45:985-997. }\end{array}$ \\
\hline 41 & $\begin{array}{l}\text { Rudiak-Gould, P. (2012). Promiscuous corroboration and climate change translation: A case study } \\
\text { from the Marshall Islands. Global Environmental Change (2012) } 22: 46-54 \text {. }\end{array}$ \\
\hline 42 & $\begin{array}{l}\text { Rudiak-Gould, P. (2014). The Influence of Science Communication on Indigenous } \\
\text { Climate Change Perception: Theoretical and Practical } \\
\text { Implications. Human Ecology (2014) 42:75-86. }\end{array}$ \\
\hline 43 & $\begin{array}{l}\text { Turner, N. J.; Clifton, H. (2009). "It's so different today": Climate change and indigenous lifeways in } \\
\text { British } \\
\text { Columbia, Canada. Global Environmental Change (2009) 19:180-190. }\end{array}$ \\
\hline 44 & $\begin{array}{l}\text { Li, C.; Ting, Z.; Rasaily, R. G. (2010). Farmer's Adaptation to Climate Risk in the Context of China -A } \\
\text { research on Jianghan Plain of Yangtze River Basin. Agriculture and Agricultural Science Procedia } \\
\text { (2010) 1:116-125. }\end{array}$ \\
\hline 45 & $\begin{array}{l}\text { Ho, P.; Azadi, H. (2010). Rangeland degradation in North China: Perceptions of pastoralists. } \\
\text { Environmental Research (2010) 110:302-307. }\end{array}$ \\
\hline 46 & $\begin{array}{l}\text { Baivaland, B.; Fernández-Giménez, M. E. (2012). Meaningful Learning for Resilience Building } \\
\text { Among Mongolian Pastoralists. Nomadic Peoples vol. } 16 \text { (2012). 2:53-77. }\end{array}$ \\
\hline 47 & $\begin{array}{l}\text { Marin, A. (2010). Riders under storms: Contributions of nomadic herders' observations to } \\
\text { analysingclimate change in Mongolia. Global Environmental Change (2010) 20:162-176. }\end{array}$ \\
\hline 48 & $\begin{array}{l}\text { Below, T. B.; Mutabazi, K. D.; Kirschke, D.; Franke, C.; Sieber, S.; Siebert, R.; Tscherning, K. (2012). } \\
\text { Can farmers' adaptation to climate change be explained by socio-economic household-level } \\
\text { variables? Global Environmental Change (2012) 22:223-235. }\end{array}$ \\
\hline 49 & $\begin{array}{l}\text { Bryan, E.; Deressa, T. T.; Gbetibouo, G. A.; Ringler, C. (2009). Adaptation to climate change in } \\
\text { Ethiopia and South Africa: } \\
\text { options and constraint. Environmental Science \& Policy (2009) 12:413-426. }\end{array}$ \\
\hline 50 & $\begin{array}{l}\text { Bryan, E.; Deressa, T. T.; Gbetibouo, G. A.; Ringler, C. (2009). Adaptation to climate change in } \\
\text { Ethiopia and South Africa: } \\
\text { options and constraint. Environmental Science \& Policy (2009) 12:413-426. }\end{array}$ \\
\hline 51 & $\begin{array}{l}\text { Deressa, T. T.; Hassan, R. M.; Ringler, C.; Alemu, T.; Yusuf, M. (2009). Determinants of farmers' } \\
\text { choice of adaptation methods to climate change in the Nile Basin of Ethiopia. Global Environmental } \\
\text { Change } 19 \text { (2009) 2:248-255. }\end{array}$ \\
\hline 52 & $\begin{array}{l}\text { Deressa, T. T.; Hassan, R. M.; Ringler, C. (2010). Perception of and adaptation to climate change } \\
\text { by farmers in the Nile basin of Ethiopia. Journal of Agricultural Science (2010) 1-9. }\end{array}$ \\
\hline 53 & $\begin{array}{l}\text { Huho, J. M.; Ngaira, J. K. W.; Ogindo, H. O. (2009) Climate Change and Pastoral Economy in Kenya: } \\
\text { A Blinking Future. Acta Geologica Sinica (English edition) Vol. } 83 \text { (2009) 5:1017-1023. }\end{array}$ \\
\hline 54 & $\begin{array}{l}\text { Kansiime, M. K.; Wambugu, S. K.; Shisanya, C. A. (2013). } \\
\text { Perceived and Actual Rainfall Trends and Variability in Eastern Uganda: Implications for } \\
\text { Community Preparedness and Response. Journal of Natural Sciences Research } \\
\text { Vol. } 3 \text { (2013) 8:179-194. }\end{array}$ \\
\hline 55 & $\begin{array}{l}\text { Kassahun, A.; Snyman, H.A.; Smit, G.N. (2008). Impact of rangeland degradation on the pastoral } \\
\text { production } \\
\text { systems, livelihoods and perceptions of the Somali pastoralists in Eastern Ethiopia. Journal of Arid } \\
\text { Environments (2008) 72:1265-1281. }\end{array}$ \\
\hline
\end{tabular}




\begin{tabular}{|c|c|}
\hline 56 & $\begin{array}{l}\text { Kijazi, A. L.; Chang'a, L. B.; Liwenga, E. T.; Kanemba, A.; Nindi, S. J. (2013). The use of indigenous } \\
\text { knowledge in weather and climate prediction in Mahenge and Ismaniwards, Tanzania. Journal of } \\
\text { Geography and Regional Planning Vol. } 6 \text { (2013) 7: 274-280. }\end{array}$ \\
\hline 57 & $\begin{array}{l}\text { Meze-Hausken, E. (2004). Contrasting climate variability and meteorological drought with } \\
\text { perceived drought and climate change in northern Ethiopia. Climate Research (2004) 27:19-31. }\end{array}$ \\
\hline 58 & $\begin{array}{l}\text { Orlove, B.; Roncoli, C.; Kabugo, M.; Majugu, A. (2010). Indigenous climate knowledge in southern } \\
\text { Uganda: } \\
\text { the multiple components of a dynamic regional system. Climatic Change (2010) 100:243-265. }\end{array}$ \\
\hline 59 & $\begin{array}{l}\text { Paavola, J. (2008). Livelihoods, vulnerability and adaptation to climate changein Morogoro, } \\
\text { Tanzania. Environmental Science \& Policy (2008) 11:642-654. }\end{array}$ \\
\hline 60 & $\begin{array}{l}\text { Solomon, T. B.; Snyman, H.A.; Smit, G.N. (2007). Cattle-rangeland management practices and } \\
\text { perceptions of pastoralists towards rangeland degradation in the Borana zone of southern } \\
\text { Ethiopia. Journal of Environmental Management (2007) 82:481-494. }\end{array}$ \\
\hline 61 & $\begin{array}{l}\text { Ishaya, S.; Abaje, I. B. (2008). Indigenous people's perception on climate change and adaptation } \\
\text { strategies in Jema'a local government area of Kaduna State, Nigeria. Journal of Geography and } \\
\text { Regional Planning Vol.1 (2008) 8:138-143. }\end{array}$ \\
\hline 62 & $\begin{array}{l}\text { Kemausuor, F.; Dwamena, E.; Bart-Plange, A.; Kyei-Baffour, N. (2011). Farmers' Perception of } \\
\text { Climate Change in the Ejura-Sekyedumase District of Ghana. } \\
\text { ARPN Journal of Agricultural and Biological Science Vol. } 6 \text { (2011) 10:26-37. }\end{array}$ \\
\hline 63 & $\begin{array}{l}\text { Lykke, A. M. (1998). Assessment of species composition change in savanna vegetation by means of } \\
\text { woody plants' size class distributions and local information. Biodiversity and Conservation (1998) } \\
\text { 7:1261-1275. }\end{array}$ \\
\hline 64 & $\begin{array}{l}\text { Lykke, A. M. (2000). Local perceptions of vegetation change and priorities for conservation of } \\
\text { woody-savanna vegetation in Senegal. Journal of Environmental Management } \\
(2000) \text { 59:107-120 }\end{array}$ \\
\hline 65 & $\begin{array}{l}\text { Nielsen, J. Ø.; Reenberg, A. (2010). Cultural barriers to climate change adaptation: A case study } \\
\text { from Northern } \\
\text { Burkina Faso. Global Environmental Change (2010) 20:142-152. }\end{array}$ \\
\hline 66 & $\begin{array}{l}\text { Sop, T. K.; Oldeland, J. (2011). Local Perceptions of Woody Vegetation Dynamics in the } \\
\text { Context of a 'Greening Sahel': A Case Study from Burkina Faso. Land Degradation \& Development } \\
\text { (2011). }\end{array}$ \\
\hline 67 & $\begin{array}{l}\text { West, C. T.; Roncoli, C.; Ouattara, F. (2008). Local Perceptions and Regional Climate Trends on the } \\
\text { Central Plateau of Burkina Faso. Land Degradation \& Development (2008). }\end{array}$ \\
\hline 68 & $\begin{array}{l}\text { Wezel, A.; Lykke, A. M. (2006). Woody vegetation change in Sahelian West Africa: evidence from } \\
\text { local knowledge. Environment, Development and Sustainability (2006) 8:553-56. }\end{array}$ \\
\hline 69 & $\begin{array}{l}\text { Chalmers, N.; Fabricius, C. (2007). Expert and Generalist Local Knowledge about Land-cover Change } \\
\text { on } \\
\text { South Africa's Wild Coast: Can Local Ecological Knowledge Add Value to } \\
\text { Science?Ecology and Society } 12 \text { (2007) 1: } 10 .\end{array}$ \\
\hline 70 & $\begin{array}{l}\text { Klintenberg, P. ; Seely, M.; Christiansson, C. (2007). Local and national perceptions of } \\
\text { environmental change in central Northern Namibia: Do they correspond? Journal of Arid } \\
\text { Environments (2007) 69:506-52. }\end{array}$ \\
\hline 71 & $\begin{array}{l}\text { Osbahr, H.; Twyman, C.; Adger, W. N.; Thomas, D. S. G. (2008). Effective livelihood adaptation to } \\
\text { climate change disturbance: Scale dimensions of practice in Mozambique. Geoforum (2008) } \\
\text { 39:1951-1964. }\end{array}$ \\
\hline 72 & $\begin{array}{l}\text { Patt, A. G.; Schröter, D. (2008). Perceptions of climate risk in Mozambique: Implications for the } \\
\text { success of adaptation strategies. Global Environmental Change (2008) 18:458-467. }\end{array}$ \\
\hline
\end{tabular}




\begin{tabular}{|c|c|}
\hline 73 & $\begin{array}{l}\text { Boillat, S.; Berkes, F. (2013). Perception and Interpretation of Climate Change among Quechua } \\
\text { Farmers of Bolivia: Indigenous Knowledge as a Resource for Adaptive Capacity. Ecology and Society } \\
\text { (2013) } 18 \text { (4): } 21 .\end{array}$ \\
\hline 74 & $\begin{array}{l}\text { Muchagata, M.; Brown, K. (2000). Colonist farmers' perceptions of fertility and the frontier } \\
\text { environment in eastern Amazonia. Agriculture and Human Values (2000) 17:371-384. }\end{array}$ \\
\hline 75 & $\begin{array}{l}\text { Oldekop, J. A.; Bebbington, A. J.; Truelove, N. K.; Holmes, G.; \& Villamarín, S.; Preziosi, R. F. (2012). } \\
\text { Environmental Impacts and Scarcity Perception Influence Local Institutions in Indigenous } \\
\text { Amazonian Kichwa Communities. Human Ecology (2012) 40:101-115. }\end{array}$ \\
\hline 76 & $\begin{array}{l}\text { Schwartzman, S.; Boas, A. V.; Ono, K. Y.; Fonseca, M. G.; Doblas, J.; Zimmerman, B.; Junqueira, P.; } \\
\text { Jerozolimski, A.; Salazar, M.; Junqueira, R. P.; Torres, M. (2013). The natural and social history of } \\
\text { the indigenous lands and protected areas } \\
\text { corridor of the Xingu River basin. Philosophical Transactions of the Royal Society B 368: } \\
20120164 \text {. }\end{array}$ \\
\hline 77 & $\begin{array}{l}\text { Valdivia, C.; Seth, A.; Gilles, J. L.; García, M.; Jiménez, E.; Cusicanqui, J.; Navia, F.; Yucra, E. (2010). } \\
\text { Adapting to Climate Change in Andean Ecosystems: } \\
\text { Landscapes, Capitals, and Perceptions Shaping Rural } \\
\text { Livelihood Strategies and Linking Knowledge } \\
\text { Systems. Annals of the Association of American Geographers (2010) 100(4):818-834. }\end{array}$ \\
\hline 78 & $\begin{array}{l}\text { Ainsworth, C. H.; Pitcher, T.J.; Rotinsulu, C. (2008). Evidence of fishery depletions and shifting } \\
\text { cognitive baselines in Eastern Indonesia. Biological Conservation (2008) 141:848-859. }\end{array}$ \\
\hline 79 & $\begin{array}{l}\text { Bunce, M.; Rodwell, L. D.; Gibb, R.; Mee, L. (2008). Shifting baselines in fishers' perceptions of } \\
\text { island } \\
\text { reeffishery degradation. Ocean \& Coastal Management (2008) 51:285-302. }\end{array}$ \\
\hline 80 & $\begin{array}{l}\text { Anik, S. I.; Khan, M. A. S. A. (2012). Climate change adaptation through local knowledge } \\
\text { in the north eastern region of Bangladesh. Mitig Adapt Strateg Glob Change (2012) 17:879-896. }\end{array}$ \\
\hline 81 & $\begin{array}{l}\text { Codjoe, S. N. A.; Owusu, G.; Burkett, V. (2014). Perception, experience, and indigenous knowledge } \\
\text { of climate } \\
\text { change and variability: the case of Accra, a sub-Saharan } \\
\text { African city. Regional Environmental Change (2014) 14:369-383. }\end{array}$ \\
\hline 82 & $\begin{array}{l}\text { Ashraf, M.; Routray, J. K. (2013). Perception and understanding of drought and coping strategies of } \\
\text { farming households in north-west Balochistan. International Journal of Disaster Risk Reduction } \\
\text { (2013) 5:49-60. }\end{array}$ \\
\hline 83 & $\begin{array}{l}\text { Baul, T. K.; Ullah, K. M. A.; Tiwari, K. R.; McDonald, M. A. (2013). People's local knowledge of } \\
\text { climate change in the Middle-Hills of Nepal. Indian Journal of Traditional Knowledge Vol. } 12 \text { (2013) } \\
\text { 4:585-595. }\end{array}$ \\
\hline 84 & $\begin{array}{l}\text { Bola, G.; Mabiza, C.; Goldin, J.; Kujinga, K.; Nhapi, I.; Makurira, H.; Mashauri, D. (2014). Coping } \\
\text { with droughts and floods: A Case study of Kanyemba, } \\
\text { Mbire District, Zimbabwe. Physics and Chemistry of the Earth 67-69 (2014) 180-186. }\end{array}$ \\
\hline 85 & $\begin{array}{l}\text { Brewer, T. D. (2013). Dominant discourses, among fishers and middlemen, of the factors } \\
\text { affecting coral reef fish distributions in Solomon Islands. Marine Policy (2013) 37:245-25. }\end{array}$ \\
\hline 86 & $\begin{array}{l}\text { Bunce, M.; Mee, L.; Rodwell, L. D.; Gibb, R. (2009). Collapse and recovery in a remote small island- } \\
\text { A tale of adaptive cycles or downward spirals? Global Environmental Change (2009) 19:213-226. }\end{array}$ \\
\hline 87 & $\begin{array}{l}\text { Bunce, M.; Rosendo, S.; Brown, K. (2010). Perceptions of climate change, multiple stressors and } \\
\text { livelihoods on marginal African coasts. Environment, Development and Sustainability (2010) } \\
\text { 12:407-44. }\end{array}$ \\
\hline 88 & $\begin{array}{l}\text { Bunce, M.; Rosendo, S.; Brown, K. (2010). Perceptions of climate change, multiple stressors } \\
\text { and livelihoods on marginal African coasts. Environment, Development and Sustainability (2010) } \\
\text { 12:407-44. }\end{array}$ \\
\hline
\end{tabular}




\begin{tabular}{|c|c|}
\hline 89 & $\begin{array}{l}\text { Conchedda, G.; Lambin, E. F.; Mayaux, P. (2011). Between Land and Sea: Livelihoods } \\
\text { andEnvironmental Changes in Mangrove Ecosystems of Senegal. Annals of the Association of } \\
\text { American Geographers (2011) 101:6 1259-1284. }\end{array}$ \\
\hline 90 & $\begin{array}{l}\text { Davis, D. K. (2005). Indigenous knowledge and the desertification debate: problematising expert } \\
\text { knowledge in North Africa. Geoforum (2005) 36:509-52. }\end{array}$ \\
\hline 91 & $\begin{array}{l}\text { Fienup-Riordan, A.; Carmack, E. (2011). "The ocean is always changing": Nearshore and farshore } \\
\text { perspectives on Arctic coastal seas. Oceanography 24(3):266-279. }\end{array}$ \\
\hline 92 & $\begin{array}{l}\text { Furberg, M.; Evengård, B.; Nilsson, M. (2011). Facing the limit of resilience: perceptions of climate } \\
\text { change among reindeer herding Sami in Sweden. Global Health Action (2011) } 4: 8417 .\end{array}$ \\
\hline 93 & $\begin{array}{l}\text { Habiba, U.; Shaw, R.; Takeuchi, Y. (2012). Farmer's perception and adaptation practices to cope } \\
\text { with drought: Perspectives from Northwestern Bangladesh. International Journal of Disaster Risk } \\
\text { Reduction (2012) 1:72-84. }\end{array}$ \\
\hline 94 & $\begin{array}{l}\text { Haden, V. R.; Niles, M. T.; Lubell, M.; Perlman, J.; Jackson, L. E. (2012). Global and Local Concerns: } \\
\text { What Attitudes and Beliefs Motivate Farmers to Mitigate and Adapt to Climate Change?Global and } \\
\text { Local Concerns about Climate Change (2012) 7: e52882. }\end{array}$ \\
\hline 95 & $\begin{array}{l}\text { Hageback, J.; Sundberg, J.; Ostwald, M.; Chen, D.; Yun, X.; Knutsson, P. (2005). Climate variability } \\
\text { and land-use change in danangou watershed, china - examples of small-scale farmers' } \\
\text { adaptation. Climatic Change (2005) 72:189-212. }\end{array}$ \\
\hline 96 & $\begin{array}{l}\text { Hernández-Cornejo, R.; Koedam, N.; Ruiz Luna, A.; M. Troell, M.; Dahdouh-Guebas, F. (2005). } \\
\text { Remote sensing and ethnobotanical assessment of the mangrove forest changes in the Navachiste- } \\
\text { San Ignacio-Macapule lagoon complex, Sinaloa, Mexico. Ecology and Society (2005) 10(1): } 16 .\end{array}$ \\
\hline 97 & $\begin{array}{l}\text { Hofmeijer, I.; Ford, J. D.; Berrang-Ford, L.; Zavaleta, C.; Carcamo, C.; Llanos E.; Carhuaz, C.; Edge, V.; } \\
\text { Lwasa, S.; Namanya, D. (2013). Community vulnerability to the health effects of climate change } \\
\text { among indigenous populations in the Peruvian Amazon: a case study from Panaillo and Nuevo } \\
\text { Progreso. Mitigation and Adaptation Strategies for Global Change (2013) 18:957-978. }\end{array}$ \\
\hline 98 & $\begin{array}{l}\text { Huda, N. M. (2013). Understanding indigenous people's perception on climate change and climatic } \\
\text { hazards: a case study of Chakma indigenous communities in Rangamati Sadar Upazila of } \\
\text { Rangamati District, Bangladesh. Natural Hazards (2013) 65:2147-2159. }\end{array}$ \\
\hline 99 & $\begin{array}{l}\text { Ignatowski, J. A.; Rosales, J. (2013). Identifying the exposure of two subsistence villages } \\
\text { in Alaska to climate change using traditional ecological knowledge. Climatic Change (2013) } \\
\text { 121:285-299. }\end{array}$ \\
\hline 100 & $\begin{array}{l}\text { Irfanullah, H. M.; Motaleb, M. A. (2011). Reading Nature's Mind: Disaster management by indig } \\
\text { enous peoples of } \\
\text { Bangladesh. Indian Journal of Traditional Knowledge vol. } 10 \text { (2011) 1:80-90. }\end{array}$ \\
\hline 101 & $\begin{array}{l}\text { Jacob, C.; McDaniels, T.; Hinch, S. (2010). Indigenous culture and adaptation to climate change: } \\
\text { sockeye salmon and the St'át'imc people. Mitigation and Adaptation Strategies for Global Change } \\
\text { (2010) 15:859-876. }\end{array}$ \\
\hline 102 & $\begin{array}{l}\text { Kalanda-Joshua, M.; Ngongondo, C.; Chipeta, L.; Mpembeka, F. (2011). Integrating indigenous } \\
\text { knowledge with conventional science: Enhancing } \\
\text { Localised climate and weather forecasts in Nessa, Mulanje, Malawi. Physics and Chemistry of the } \\
\text { Earth (2011) 36:996-1003. }\end{array}$ \\
\hline 103 & $\begin{array}{l}\text { Knopp, J. A. (2010). Investigating the Effects of Environmental Change on Arctic Char (Salvelinus } \\
\text { Alpinus) growth Using scientific and Inuit Traditional knowledge. Infonorth (2010) 493-497. }\end{array}$ \\
\hline 104 & $\begin{array}{l}\text { Kovacs, J. M. (2000). Perceptions of environmental change in } \\
\text { a tropical coastal wetland. Land Degradation and Development (2000) 11:209-220. }\end{array}$ \\
\hline 105 & $\begin{array}{l}\text { Krupnik, I.; Ray, G. C. (2007). Pacific walruses, indigenous hunters, and climate change: Bridging } \\
\text { scientific and indigenous knowledge. Deep-Sea Research II (2007) 54:2946-2957. }\end{array}$ \\
\hline 106 & $\begin{array}{l}\text { Lammel, A.; Dugas, E.; Guillen, E. (2011). Traditional way of thinking and prediction of climate } \\
\text { change in New Caledonia (France). Indian Journal of Traditional Knowledge vol. } 10 \text { (2011) 1:13-20. }\end{array}$ \\
\hline
\end{tabular}




\begin{tabular}{|c|c|}
\hline 107 & $\begin{array}{l}\text { Leonard, S.; Parsons, M.; Olawsky, K.; Kofod, F. (2013). The role of culture and traditional } \\
\text { knowledge in climate change adaptation: Insights from East Kimberley, Australia. Global } \\
\text { Environmental Change (2013) 23:623-632. }\end{array}$ \\
\hline 108 & $\begin{array}{l}\text { Li, C.; Tang, Y.; Luo, H.; Di, B.; Zhang, L. (2013). Local Farmers' Perceptions of Climate Change and } \\
\text { Local Adaptive Strategies: A Case Study from the Middle Yarlung Zangbo River Valley, Tibet, China. } \\
\text { Environmental Management (2013) 52:894-906. }\end{array}$ \\
\hline 109 & $\begin{array}{l}\text { Liu, Z.; Smith Jr, W. J.; Safi, A. S. 2014. Rancher and farmer perceptions of climate change } \\
\text { in Nevada, USA. Climatic Change (2014) 122:313-327. }\end{array}$ \\
\hline 110 & $\begin{array}{l}\text { Manandhar, S.; Vogt, D. S.; Perret, S. R.; Kazama, F. (2011). Adapting cropping systems to climate } \\
\text { change in Nepal: a cross-regional study of farmers' perception and practices. Regional } \\
\text { Environmental Change (2011) 11:335-348. }\end{array}$ \\
\hline 111 & $\begin{array}{l}\text { Marschke, M.; Lykhim, O.; Kim, N. (2014). Can } \\
\text { Local Institutions Help Sustain Livelihoods in an Era of Fish Declines and Persistent Environmental } \\
\text { Change? A Cambodian Case Study. Sustainability } \\
\text { (2014) 6:2490-2505. }\end{array}$ \\
\hline 112 & $\begin{array}{l}\text { Mbow, C.; Mertz, O.; Diouf, A.; Rasmussen, K.; Reenberg, A. (2008). The history of environmental } \\
\text { change and adaptation in eastern Saloum -Senegal-Driving forces and perceptions. Global and } \\
\text { Planetary Change (2008) 64: 210-221. }\end{array}$ \\
\hline 113 & $\begin{array}{l}\text { McCarthy, A.; Hepburn, C.; Scott, N.; Schweikert, K.; Turner, R.; Moller, H. (2014). Local people see } \\
\text { and care most? Severe depletion of inshore fisheries and its consequences for Māori communities in } \\
\text { New Zealand. Aquatic Conservation: Marine and Freshwater Ecosystems (2014) 24: 369-390. }\end{array}$ \\
\hline 114 & $\begin{array}{l}\text { MacDonald, J. P.; Harper, S. L.; Willox, A. C.; Edge, V. L.; Rigolet Inuit Community Government } \\
\text { (2013). A necessary voice: Climate change and lived experiences of youth in Rigolet, Nunatsiavut, } \\
\text { Canada. Global Environmental Change (2013) 23:360-371. }\end{array}$ \\
\hline 115 & $\begin{array}{l}\text { Nichols, T.; Berkes, F.; Jolly, D.; Snow, N. B. (2004). Climate Change and Sea Ice: Local Observations } \\
\text { from the Canadian Western Arctic. Arctic vol } 57 \text { (2004) 1:68-79. }\end{array}$ \\
\hline 116 & $\begin{array}{l}\text { Nkomwa, E. C.; Kalanda-Joshua, M.; Ngongondo, C.; Monjerezi, M.; Chipungu, F. (2014). Assessing } \\
\text { indigenous knowledge systems and climate change adaptation strategies in agriculture: A case } \\
\text { study of Chagaka Village, Chikhwawa, Southern Malawi. Physics and Chemistry of the Earth (2014) } \\
67-69: 164-172 .\end{array}$ \\
\hline 117 & $\begin{array}{l}\text { Qiang-yi, Y.; Wen-bin, W.; Zhen-huan, L.; Verburg, P. H.; Tian, X.; Peng, Y.; Zhong-jun, L.; Liang-zhi, } \\
\text { Y.; Hua-jun, T. (2014). Interpretation of Climate Change and Agricultural Adaptations by Local } \\
\text { Household Farmers: a Case Study at Bin County, Northeast China. Journal of Integrative Agriculture } \\
\text { (2014) 13(7): 1599-1608. }\end{array}$ \\
\hline 118 & $\begin{array}{l}\text { Rana, R. S.; Bhagat, R. M.; Kalia, V.; Lal, H.; Sen, V. (2013). Indigenous perceptions of Climate } \\
\text { change vis-a-vis Mountain Agricultural activities in Himachal Pradesh, India. Indian Journal of } \\
\text { Traditional Knowledge Vol. } 12 \text { (2013) 4:596-604. }\end{array}$ \\
\hline 119 & $\begin{array}{l}\text { Sánchez-Cortés, M. S.; Chavero, E. L. (2011). Indigenous perception of changes in climate variability } \\
\text { and its relationship with agriculture in a Zoque community of Chiapas, Mexico. Climatic Change } \\
\text { (2011) 107:363-389. }\end{array}$ \\
\hline 120 & $\begin{array}{l}\text { Singh, R. K.; Bhowmik, S. N.; Pandey C. B. (2011). Biocultural diversity, climate change and } \\
\text { livelihood security of the Adi community: Grassroots conservators of eastern Himalaya Arunachal } \\
\text { Pradesh. Indian Journal of Traditional Knowledge vol. } 10 \text { (2011) 1:39-56. }\end{array}$ \\
\hline 121 & $\begin{array}{l}\text { Speranza, C. I.; Kiteme, B.; Ambenje, P.; Wiesmann, U.; Makali, S. (2010). Indigenous knowledge } \\
\text { related to climate variability and change: insights from droughts in semi-arid areas of former } \\
\text { Makueni District, Kenya. Climatic Change (2010) 100:295-315. }\end{array}$ \\
\hline 122 & $\begin{array}{l}\text { Varadan, R. J.; Kumar, P. (2014). Indigenous knowledge about climate change: Validating the } \\
\text { perceptions of dryland farmers in Tamil Nadu. Indian Journal of Traditional Knowledge } \\
\text { vol. } 13 \text { (2014). 2:390-397. }\end{array}$ \\
\hline 123 & $\begin{array}{l}\text { Veland, S.; Howitt, R.; Dominey-Howes, D.; Thomalla, F.; Houston, D. (2013). Procedural } \\
\text { vulnerability: Understanding environmental change in a remote indigenous community. Global }\end{array}$ \\
\hline
\end{tabular}




\begin{tabular}{|l|l|}
\hline 124 & Environmental Change (2013) 23:314-326. \\
\hline 125 & $\begin{array}{l}\text { Wezel, A.; Haigis, J. (2000). Farmers Perception of Vegetation Changes in Semi-Arid Niger. Land } \\
\text { Degradation \& Development (2000) 11:523-534. }\end{array}$ \\
$\begin{array}{l}\text { Willox, A. C.; Harper, S. L.; Ford, J. D.; Landman, K.; Houle, K.; Edge, V. L.; the Rigolet Inuit } \\
\text { place, and health in Nunatsiavut, Canada. Social Science \& Medicine (2012) 75:538-547. }\end{array}$ \\
\hline 126 & $\begin{array}{l}\text { Willox, A. C.; Harper, S. L.; Edge, V. L.; Landman, K.; Houle, K.; Ford, J. D.; the Rigolet Inuit } \\
\text { Community Government (2013). The land enriches the soul: On climatic and environmental } \\
\text { change, affect, and emotional health and well-being in Rigolet, Nunatsiavut, Canada. Emotion, } \\
\text { Space and Society (2013) 6:14-24. }\end{array}$ \\
\hline 127 & $\begin{array}{l}\text { Wolf, J.; Allice, I.; Bell, T. (2013). Values, climate change, and implications for adaptation: Evidence } \\
\text { from two communities in Labrador, Canada. Global Environmental Change (2013) 23:548-562. }\end{array}$ \\
\hline
\end{tabular}


Appendix 3. Original Data Matrix

Please click here to download file 'appendix3.ods'. 